Mateus Furlanetto de Oliveira

\title{
Memória do Efêmero: comunicação e memória no processo de institucionalização de grupos de teatro
}


Mateus Furlanetto de Oliveira

\title{
Memória do Efêmero: comunicação e memória no processo de institucionalização de grupos de teatro
}

\author{
Dissertação de Mestrado apresentada ao \\ Programa de Pós-Graduação em Ciências \\ da Comunicação (PPGCOM) - área III - \\ Interfaces Sociais da Comunicação da \\ Escola de Comunicações e Artes da \\ Universidade de São Paulo como \\ exigência parcial para a obtenção do título \\ de Mestre em Ciências da Comunicação. \\ Orientador: Prof. Dr. Paulo Roberto \\ Nassar de Oliveira
}

\section{São Paulo}




\section{FICHA CATALOGRÁFICA}

Autorizo a reprodução e divulgação total ou parcial deste trabalho, por qualquer meio convencional ou eletrônico, para fins de estudo e pesquisa desde que citada completamente a fonte.

\section{Catalogação na publicação \\ Serviço de Biblioteca e Documentação \\ Escola de Comunicações e Artes da Universidade de São Paulo}

Oliveira, Mateus Furlanetto de

Memória do efêmero: comunicação e memória no processo de institucionalização de grupos de teatro / Mateus Furlanetto de Oliveira São Paulo : M. F. Oliveira, 2011.

$84 \mathrm{p}$.

Dissertação (Mestrado) - Escola de Comunicações e Artes / Universidade de São Paulo.

Orientador: Paulo Roberto Nassar de Oliveira

1. Relações públicas 2. Comunicação organizacional 3. Comunicação empresarial 4. Artes cênicas 5. Memória institucional I. Oliveira, Paulo Roberto Nassar de II. Título 


\section{TERMO DE APROVAÇÃO}

Nome do autor: Mateus Furlanetto de Oliveira

Título da dissertação: Memória do Efêmero: comunicação e memória no processo de institucionalização de grupos de teatro

Dissertação de Mestrado apresentada ao programa da Pós-Graduação em Ciências da Comunicação (PPGCOM) da Escola de Comunicações e Artes da Universidade de São Paulo como exigência parcial para a obtenção do título de Mestre em Ciências da Comunicação.

Orientador: Prof. Dr. Paulo Roberto Nassar de Oliveira

\section{BANCA EXAMINADORA}

Prof. Dr.:

Instituição:

Julgamento:

Assinatura:

Prof. Dr.:

Instituição:

Julgamento:

Assinatura:

Prof. Dr.:

Instituição:

Julgamento:

Assinatura:

\section{Aprovado em:}

São Paulo, 


\section{AGRADECIMENTOS}

Aos meus pais,

Aos meus familiares,

Ao meu orientador, Prof. Dr. Paulo Nassar,

Aos membros da banca de qualificação: Profa. Dra. Margarida M. Krohling

Kunsch e Prof. Dr. Mário Vitor Santos,

Aos meus colegas da Aberje,

A Else Lemos, Fabiana Furlanetto, Gisele Souza e Gustavo Palma. 


\section{RESUMO}

OLIVEIRA, Mateus Furlanetto de. Memória do Efêmero: comunicação e memória no processo de institucionalização de grupos de teatro. São Paulo, 2011. 84 p. Dissertação (Mestrado) - Departamento de Relações Públicas, Propaganda e Turismo, Escola de Comunicações e Artes, Universidade de São Paulo.

Resumo: Analisa o contexto em que se inserem os grupos de teatro e seus públicos, suas características específicas e de que forma ações de Comunicação e de Relações Públicas podem provocar e influenciar o relacionamento entre ambos. A partir principalmente de produtos e projetos de memória de grupos de teatro, é possível identificar os potenciais de comunicação que contribuem para a formação e fortalecimento da imagem institucional desses grupos. Embora seja um paradoxo trabalhar a perpetuidade de uma arte cuja natureza é efêmera, encontramos no Grupo Galpão uma série de ações, projetos e produtos que demonstram que é possível, por meio de um projeto consistente, valorizar a imagem e reputação de grupos de teatro.

Palavras-chave: Relações Públicas; Comunicação Organizacional; Comunicação Empresarial; Artes Cênicas; Memória Institucional. 


\title{
ABSTRACT
}

OLIVEIRA, Mateus Furlanetto. Ephemeral Memory: communication and memory in the process of institutionalization of theater groups São Paulo, 2011. 84 p. Dissertation (Master in Communications Science) - Departamento de Relações Públicas, Propaganda e Turismo, Escola de Comunicações e Artes, Universidade de São Paulo.

\begin{abstract}
This study seeks to analyse the context of theater groups and their publics/audiences, their specifities and how Communication and Public Relations actions can cause and influence their relationship. Based primarily on memory products and projects of theater groups, it is possible to identify the potential of communication that contributes to the formation and strengthening of the institutional image of these groups. Although working the perpetuity of an art whose nature is ephemeral seems to be a paradox, the Galpão Theater Group keeps a set of actions, projects and products which show us that it is possible to enhance the image and reputation of a theater group by means of a consistent project.
\end{abstract}

Key-words: Public Relations; Organization Communication; Business Communication; Performing Arts; Institutional Memory 
1. INTRODUÇÃO 09

1.1 CENAS INICIAIS DESTA PESQUISA 09

1.2 INTERESSE PELO TEMA 12

1.3 INTERLOCUTORES E MODOS DE OLHAR ESPECÍFICOS 15

2. A ARTE DA COMUNICAÇÃO E DAS RELAÇÕES PÚBLICAS 18

2.1 SINGULARIDADES DO PÚBLICO DAS ARTES 25

3. O PARADOXO DA MEMÓRIA DO TEATRO 32

3.1 TEATRO: ENTRE O EFÊMERO E O PERPÉTUO 37

4. VESTÍGIOS DO TEATRO 43

4.1 FRAGMENTOS DE CENAS 44

4.3 A HISTÓRIA AO ALCANCE DAS MÃOS 51

4.4 LINGUAGENS HÍBRIDAS 54

5. GRUPO GALPÃO: ONTEM, HOJE E SEMPRE 58

5.1 BREVE HISTÓRICO 59

5.2 PRODUTOS E PROJETOS DE MEMÓRIA 62

5.2.1 CDs com Trilhas Sonoras dos Espetáculos 68

5.2.2 DVDs Documentário e de Espetáculos 68

$\begin{array}{ll}\text { 5.2.3 Programas dos Espetáculos } & 70\end{array}$

5.2.4 Website de Grupo Galpão 73

5.2.5 Centro de Pesquisa e Memória do Teatro 75

6. CONCLUSÃO

7. REFERÊNCIAS 81 
O teatro não chega a alguém,

alguém faz "chegar" o teatro a si mesmo.

Carlos Tindemans 


\section{INTRODUÇÃO}

\subsection{CENAS INICIAIS DESTA PESQUISA}

Este trabalho lida com o teatro, ou seja, com uma manifestação artística que, de acordo com a sua definição tradicional, caracteriza-se fundamentalmente pela presença concomitante de atores e atrizes com os seus espectadores num mesmo espaço, ao mesmo tempo. $\mathrm{Na}$ sociedade contemporânea este conceito ganha novas significações uma vez que já há experimentos teatrais que rompem com esta singularidade. Esta ação, efêmera e impossível de se repetir, na qual "existe em um caráter de fuga perpétua. O seu momento de expressão é ironicamente o seu momento de extinção" (KOPP, 1995, p.6, tradução nossa) é uma das principais características que marcaram o teatro ao longo de seus mais de 2.500 anos de história no Ocidente.

Até se chegar ao momento do encontro entre os artistas e seu público, na forma de uma apresentação do espetáculo, é necessário que os artistas passem por uma série de processos de criação e de produção. Além disso, é necessário fazer uso de algum tipo de ação de comunicação e relacionamento para viabilizar apoios e patrocínios e também atrair os espectadores. Estes, paralelamente, também passam por processos distintos e próprios de educação, que geram, por sua vez, interesse, neste campo artístico, até a ação concreta em ir até o local da encenação da peça, compra ou retirada do ingresso para assistir à obra e fruir de uma experiência artística.

Comunicação e relacionamento são instrumentos necessários para tornar conhecidos os artistas, os grupos e os espetáculos. Somente a partir de informações recebidas diretamente dos grupos ou mediadas por terceiros (mídia, escola, amigos, entre outros), o teatro desperta no público o interesse de estar presente e assistir a um espetáculo. 
A comunicação isoladamente não é capaz de resolver toda a questão de levar o público até os artistas, pois há outras razões mais profundas, complexas e estruturais na formação dos indivíduos e da sociedade como um todo, que facilitam ou inibem o contato dos indivíduos com as artes. Pesquisas demonstram o papel fundamental da educação para despertar o interesse dos indivíduos em buscar ter contato com as múltiplas formas de expressões artísticas.

A adequação desta pesquisa à linha de Políticas e Estratégias de Comunicação na área das Interfaces Sociais da Comunicação ocorre no sentido de que é necessário ampliar o olhar e identificar as particularidades das artes no momento de se implantarem ações de comunicação e relacionamento adaptadas às singularidades das expressões artísticas e seus públicos.

No âmbito das artes cênicas, o arcabouço técnico e conceitual da Comunicação e das Relações Públicas pode contribuir para a concepção das políticas, estratégicas e ações de comunicação e relacionamento de um grupo de teatro. Tradicionalmente podem atuar na formação e no fortalecimento da sua identidade, imagem e reputação, na promoção e divulgação de espetáculos e processos de criação, auxiliar na elaboração de materiais de captação de recursos para viabilizar financeiramente os projetos e atuar na produção executiva. Mais recentemente surgiu também a oportunidade de contribuir para a constituição de projetos de memória institucional, inseri-los nas redes digitais, com o objetivo maior de trabalhar a institucionalização deste grupo na sociedade. Institucionalizar significa tornar uma organização relevante por meio de sua identidade, seus valores e práticas para toda a sociedade (NASSAR, 2008a).

No ambiente teatral atual, há uma disputa muito grande pela atenção do espectador. Como exemplo dessa competição, para citar apenas um dos veículos que publicam esse tipo de informação, o "Guia Cultural Boca-aBoca", uma das publicações de periodicidade semanal mais completa com a programação cultural da cidade de São Paulo, na semana de 5 a 11 de agosto de 2011, trazia como sugestão cultural 95 shows, 100 exposições, 176 peças teatrais, e mais de 34 filmes. 
Essa situação de concorrência acirrada é radicalizada pela baixa freqüência, hábitos, fruição e consumo de atividades artísticas por parte da população, segundo pesquisas realizadas pelo IPEA - Instituto de Pesquisa Econômica Aplicada (IPEA, 2010) ${ }^{1}$, e pelo Datafolha, Fundação Getúlio Vargas \& J. Leiva Cultura e Esporte ${ }^{2}$ focadas nos hábitos culturais. Em função da profusão de atividades artísticas ofertadas, os artistas ou grupos que gozarem de maior visibilidade, imagem e reputação conseguirão se destacar dentre a centena de opções de peças e fazer com que mensagens e informações sobre seus espetáculos ou processos criativos cheguem ao público e despertem nele o desejo e a vontade de fruir uma obra ou experiência artística.

É difícil contestar a força e a representatividade que os textos escritos por críticos, jornalistas e estudiosos sobre determinado artista ou espetáculo têm na divulgação e na institucionalização das peças e dos grupos de teatro, uma vez que esses textos são as principais fontes de consulta disponíveis para o público. Este mesmo material, posteriormente ao seu papel de caráter informativo, será um elemento fundamental na construção da narrativa desta arte. O olhar dos jornalistas e de críticos especializados é muito importante para que a informação sobre um determinado espetáculo chegue junto ao seu público espectador potencial. Apesar dos espaços dedicados ao teatro nos jornais impressos terem diminuído ao longo do tempo e a profundidade das análises ficarem comprometidas em função da limitação do espaço do texto nos jornais e revistas.

O surgimento de projetos e produtos voltados à memória das artes, com o objetivo de difundir, ampliar e expandir as oportunidades de contato e comunicação dos artistas com seus respectivos públicos possibilitam aos criadores atuarem ou influenciarem de forma pró-ativa na construção de sua

\footnotetext{
${ }^{1}$ A Pesquisa do IPEA integra o Sistema de Indicadores de Percepção Social (SIPS). Esse estudo que busca identificar os obstáculos para o acesso à cultura dos Brasileiros, foi analisado pelos técnicos de Planejamento e Pesquisa Frederico Barbosa, Herton Ellery Araújo e Ana Codes e foi divulgado em 17 de novembro de 2010.

${ }^{2}$ Pesquisa Hábitos Culturais da População Paulista, desenvolvida pela J. Leiva Cultura e Esporte, Datafolha e Fundação Getúlio Vargas, com uma amostra de 2.214 pessoas, de 82 cidades do Estado de São Paulo. O período de entrevistas ocorreu entre 24 de agosto e 20 de setembro de 2010.
} 
própria narrativa histórica e de memória. Tentando com isso lutar contra o desaparecimento do espetáculo cuja natureza é efêmera.

O peculiar, no caso das artes cênicas, é que em alguns casos, estes projetos ou produtos podem ter um duplo papel. Ao mesmo tempo em que são materiais documentais com uma função importante de preservação da memória do grupo também possuem um potencial de comunicação, promoção, divulgação e produto. No caso da arte efêmera, não é fácil de identificar, se é que existem, as fronteiras onde termina o caráter de memória e começa a comunicação. Ao longo do trabalho, citaremos algumas destas iniciativas relevantes que demonstram a aplicação destas atividades.

\subsection{INTERESSE PELO TEMA}

Meu interesse pelo teatro surgiu ainda na juventude, na cidade onde nasci e morava na ocasião, situada no interior do estado de São Paulo. Aproximadamente uma vez por mês uma peça de teatro em turnê pelo país, normalmente com algum ator ou atriz de evidência na TV no elenco do espetáculo, apresentava-se na cidade. Não perdia nenhuma apresentação! $O$ tema da peça me era indiferente, o que importava é que era teatro. la ao teatro pelo simples fato de ser teatro. Comprava o ingresso tão logo iniciava a venda para conseguir um bom lugar. Ainda guardo em minhas memórias algumas cenas, trechos, músicas. Guardo comigo fisicamente praticamente todos os ingressos e programas de peças assistidas, algumas críticas e reportagens de espetáculos e grupos de que mais gosto, pois dado o caráter efêmero do teatro, sinto que estes simples pedaços de papel são o que de alguma forma materializam este encontro único que não se repetirá jamais. É impressionante a carga de memória que emerge ao manusear estes materiais.

Ao mudar para São Paulo e iniciar os estudos de Comunicação Social com habilitação em Relações Públicas, tive enfim a oportunidade de assistir a praticamente todos os espetáculos que desejava. Porque quando ainda morava no interior, lia diariamente os cadernos de cultura do jornal $O$ Estado de 
São Paulo e assistia ao programa Metrópolis, da TV Cultura, e lamentava o fato de não poder assistir aos espetáculos que estavam em cartaz na ocasião e eram foco das reportagens e críticas apresentadas nestas mídias.

Desde esta época passei a ampliar o meu repertório artístico. Com o passar do tempo, além do ingresso e do programa comecei a levar para casa livros com roteiro do espetáculo ou sobre a história dos grupos, CDs com canções de cena, DVDs com a filmagem dos espetáculos, camisetas e programas das peças.

Atualmente, na internet, é possível ver uma série de vídeos com cenas dos espetáculos, cenas de ensaios, fotografias, blogs de processos criativos de espetáculos, sites de críticas feitas por jornalistas e fotógrafos (blogs Teatrojornal do jornalista Valmir Santos e Cacilda Blog de Teatro da Lenise Pinheiro do Nelson de Sá), estudantes, interessados e pessoas que não trabalham nas mídias tradicionais (blog da Bacante), enfim, novas e múltiplas fontes alternativas de informação e conteúdo que estão transformando o modo de comunicação e relacionamento do público com o artista e deste com o público até chegar aos sites que veiculam a íntegra dos espetáculos teatrais online (Cennarium).

Assisto desde espetáculos de puro entretenimento às propostas experimentais mais intensas. De grupos consagrados a grupos iniciantes. Dos teatros de "elite" aos teatros de bairro. De grandes produções internacionais a performances na casa do próprio artista. E o que sempre me intrigou e intriga até hoje, tendo sido intensificado pela minha formação na ECA/USP, a partir do olhar de comunicador e relações-públicas é saber o que levou ou não levou o público àquelas apresentações? Por que espetáculos gratuitos ou a um custo baixo não tinham muito público? Por que determinados teatros ou espetáculos de determinados grupos ou artistas estão praticamente lotados? Por que os cadernos e revistas de cultura dão destaques para os mesmos espetáculos? Os esforços de comunicação empregados na divulgação do espetáculo foram suficientes, insuficientes ou exagerados? Por que há espetáculos que nos marcam profundamente e outros de que não lembramos nada? O que mudará no relacionamento entre artistas e público na plataforma da mídia digital, onde o 
contato poderá ser direto sem a mediação e o filtro de um crítico ou jornalista? Onde o próprio público se torna um agente de divulgação do artista? Enfim, muitas perguntas, que acredito não sejam apenas indagações pessoais. Evidentemente, não é do escopo deste trabalho encontrar suas respostas, ainda que algumas considerações possam servir como tal.

Além disso, conheço e convivo com alguns artistas de teatro e observo que há um grande desconhecimento sobre produção, gestão, empreendedorismo e comunicação por parte deles. Estão focados em seus processos criativos e acham que o público, as matérias nos jornais, os editais, os orçamentos surgirão espontaneamente uma vez que eles estão produzindo obras com alto rigor e qualidade artística. Não raro, há espetáculos cujo pouco público que conquistam é composto por amigos, parentes e integrantes da classe teatral e artística. Quais as possibilidades concretas de transformação deste quadro?

As questões são muitas e complexas. Um único estudo não é suficiente para respondê-las. A intenção deste estudo é identificar e revelar as possibilidades que se apresentam na configuração contemporânea das artes cênicas e as influências exercidas pela comunicação neste ambiente.

Sendo assim, esta dissertação é composta por quatro capítulos. No primeiro capítulo, abordamos os pontos de contato da Comunicação, das Relações Públicas e do Marketing com o meio artístico, as peculiaridades do público frequentador e apreciador das artes, as forças exercidas pela economia da cultura nesse contexto e qual o sentido mais apropriado associado ao termo marketing cultural.

No segundo capítulo, apresentamos as especificidades de teatro e o seu caráter efêmero, as formas de registros disponíveis para este tipo de arte e o paradoxo entre a arte efêmera e seus suportes de registros e documentação.

No terceiro capítulo, descrevemos os principais tipos documentais presentes na memória do teatro como os textuais, iconográficos, audiovisuais e os produtos gerados a partir deles, tais como livros, filmes e DVDs. Recursos estes já presentes na realidade de muitos grupos, porém necessitando de maior visibilidade. 
No quarto capítulo, descrevemos os produtos e projetos de memória do Grupo Galpão, procurando demonstrar a consistência e permanência com que o Grupo trabalha sua memória. A pesquisa foi integralmente realizada a partir dos próprios materiais e produtos ligados à memória do Grupo Galpão obtidos ao longo de dezoito anos. A escolha do Grupo Galpão se deu em função de ser ele o grupo com a maior diversidade e quantidade de produtos e projetos de memória do teatro.

O objetivo desta pesquisa consiste em levantar as características específicas do meio artístico para orientar as estratégias e ações de comunicação e relacionamento a serem aplicadas em grupos de teatro, indo além das ações tradicionais, destacando as práticas voltadas à memória institucional.

O foco do nosso estudo é a identificação de produtos e projetos de memória de grupos de teatro contemporâneos e a contribuição que estes projetos têm para a institucionalização destes grupos perante seus públicos. Processo este, que, atualmente, é permeado por uma nova oportunidade de contato dos grupos com seus públicos, por meio das mídias audiovisuais e digitais e da ampliação do acesso às tecnologias de informação e comunicação.

Desejamos também, com esta pesquisa, identificar alguns tipos de registros, de documentos de espetáculos e/ou processos de criação de grupos de teatro e os benefícios dos projetos de memória na valorização da imagem dos grupos de teatro, na tentativa de apontar novas possibilidades de comunicação e de relacionamento dos grupos de teatro com seus públicos.

\subsection{INTERLOCUTORES E MODOS DE OLHAR ESPECÍFICOS}

Esta pesquisa entra em interlocução com teóricos das Ciências Sociais Aplicadas, Comunicação Social, Relações Públicas, Marketing e Artes Cênicas.

Do campo da Comunicação Social e das Relações Públicas nos ancoramos nos estudos de Kunsch (1997, 2007), Nassar (1999, 2006, 2007, 
2008a, 2008b), Barros (2007), Machado Neto (2007) e nos seus modos de olhar para as relações públicas e sua conexão com o ambiente cultural e artístico.

Buscamos apoio também na literatura americana do Marketing focado nas artes cênicas e performáticas por meio dos estudos de Kotler e Scheff (1997) e Bernstein (2007).

Nosso trabalho proporciona uma interface com teóricos do campo das artes cênicas, Bertold (2004), Lehmann (2007), Rebello (2005), Pavis (2005), Picon-Valin (2008) e Rosenfeld (2009).

Utilizamos também as próprias obras e materiais de projetos de memória gerados pelos grupos teatrais. O foco de nossa análise não é o conteúdo total das obras, mas a partir dos textos das seções Prefácio, Introdução e Apresentação, recolhemos posicionamentos, reflexões, impressões, pistas e opiniões declaradas sobre os objetivos e orientações da realização dos respectivos produtos.

Nosso estudo tem caráter descritivo e exploratório. Os procedimentos metodológicos que norteiam a dissertação aqui apresentada estão fundamentados em uma revisão da literatura pertinente, aqui entendida como "uma atividade contínua e constante em todo trabalho acadêmico e de pesquisa, iniciando a formulação do problema e/ou objetivos de estudo e indo até a análise de resultados" (STUMPF, 2010, p. 52). Buscamos autores que investigam e discutem a temática contemporânea da comunicação organizacional e das artes cênicas no sentido de encontrar os pontos de contato entre estes dois campos.

Em seguida, realizamos um estudo de caso baseado exclusivamente na análise documental (YIN, 2001), para complementar qualitativamente os dados. A finalidade desse método de pesquisa "pode ser empregada para o tipo descritivo, em que o pesquisador busca mapear uma situação ou campo de análise, descrever e focar determinado contexto" (DUARTE, 2010 p. 64). A partir de um levantamento dos produtos dos grupos de teatro brasileiros que já produziram materiais referentes à sua história e memória, escolhemos o Grupo Galpão por ser um dos pioneiros neste campo e possuir o leque mais diversificado de produtos voltados a esse tema. 
Optamos pela análise dos materiais produzidos pelo Grupo Galpão nos últimos 18 anos a que tivemos acesso por meio da distribuição ou compra após a apresentação dos espetáculos ou na própria sede do grupo $A$ aquisição desses materiais (livros, CDs, DVDs e programas) de modo espontâneo, ou seja, disponível a qualquer indivíduo que tenha assistido a um espetáculo, fortalece este trabalho, pois demonstra a preocupação e o compromisso do grupo em tornar público e acessível aos seus espectadores os produtos relacionados às suas peças, sua história e sua memória.

Esta pesquisa é um convite à memória do efêmero, que só se realiza, perpetua-se na interação entre espectador e obra de arte. Estamos, portanto, juntos em cena... 


\section{A ARTE DA COMUNICAÇÃO E DAS RELAÇÕES PÚBLICAS}

Os estudos e as teorias da Comunicação e das Relações Públicas são fortemente baseados e influenciados pela estrutura de empresas e instituições. Essas organizações, como especifica Nassar (2008a) podem ser definidas como "um sistema social e histórico, formal, que obrigatoriamente se comunica e se relaciona, de forma endógena, com outros sistemas sociais e com a sociedade" (p. 62). Além disso, possuem características comuns, "a) são sistemas sociais constituídos por relacionamentos entre pessoas; b) são complexas e aplicam a divisão do trabalho; c) têm história e memória; d) devem enfrentar o desafio das mudanças; e) têm identidade; e f) querem resultados" (NASSAR, 2008a, p. 62-63).

Os grupos de teatro formalmente constituídos se caracterizam como organizações uma vez que são constituídos por pessoas que desempenham funções específicas, embora neste meio seja comum haver o acúmulo de funções. Como é o caso de atores que também realizam o trabalho administrativo e contábil, diretores que assumem a função de produtor, atrizes que exercem também as atividades de comunicação. Ou seja, limitações orçamentárias podem provocar aos membros artísticos do grupo o exercício de forma secundária de atividades ligadas à gestão, produção e comunicação.

A identificação imediata do nome dos grupos de teatro ao nome de seus fundadores ou diretores é uma característica constante neste tipo de organização. Por exemplo, é difícil desassociar o nome de José Celso Martinez Correa, do Teatro Oficina Uzyna Uzona; de Antônio Araújo, do Teatro da Vertigem; de Enrique Diaz, da Cia. dos Atores, entre outros.

Essa identificação se forma a partir da constituição história desses grupos e o legado deixado a partir de suas encenações. Cada grupo desenvolve um tipo de trabalho marcado por uma proposta estética, poética e artística. A expressão pública deste trabalho em conjunto com as ações cotidianas nos processos criativos e produtivos do grupo resulta na constituição de sua identidade. Segundo Nassar, "cada organização expressa a sua cultura em uma determinada identidade. Esta é constituída de um conjunto de símbolos, 
comportamentos e narrativas que a tornam única diante de seus públicos, redes de relacionamento e sociedade" (NASSAR, 2008a, p. 63).

Em termos organizacionais, o resultado principal que um grupo de teatro deseja com o seu trabalho é montar um espetáculo, que atraia público, e permita a subsistência econômica do grupo visando a continuidade de seu projeto artístico. O ciclo de um espetáculo é permeado por relacionamentos e contatos com diversos agentes sociais. Desde a ideia artística inicial, o processo criativo, a montagem do espetáculo, captação de apoios e patrocínios, estréia da peça, contato com os espectadores até as repercussões na mídia e na sociedade.

Diferentemente das organizações empresariais na qual um dos principais resultados esperados é o lucro. No caso das companhias de teatro, embora necessitem manter-se economicamente, por se tratar de uma forma de expressão artística, estes grupos são movidos principalmente pelo desejo de diálogo e transformação do indivíduo e da sociedade.

Deste modo, a abordagem das políticas, estratégias e ações de comunicação e relacionamento voltadas para os grupos de teatro deve estar ancorada nos princípios e valores desses grupos.

O livro Relações Públicas Comunitárias: a comunicação em uma perspectiva dialógica e transformadora ( $\mathrm{KUNSCH}, \mathrm{M}$. e $\mathrm{KUNSCH}, \mathrm{W} ., 2007$ ) aponta formas específicas de atuação da atividade de relações públicas, voltadas para os interesses de organizações sociais cujo foco principal não está no resultado financeiro, mas na transformação da sociedade. São ações ligadas ao terceiro setor, movimentos populares ou comunitários, projetos sociais, projetos de cidadania e projetos culturais. Segundo Barros, "as atividades de comunicação institucional, historicamente, têm se voltado basicamente para o aspecto formal e sistêmico da sociedade, ou seja, as relações das empresas e instituições com seus públicos. (...) pouco se tem enfatizado o potencial dessa área da comunicação com a cultura, e em seu sentido mais abrangente" (2007, p.124).

Nosso foco de interesse é tratar desse aspecto da Comunicação e das Relações Públicas voltadas à comunicação e ao relacionamento no âmbito das artes. 
No contexto atual, existem demandas crescentes para a atuação do profissional de comunicação institucional em outros níveis (...) na esfera sociocultural que contribui para manter a identidade social e cultural dos indivíduos e comunidades, ao favorecer compartilhamento de valores, a livre expressão de idéias. (BARROS, 2007, p.124-125)

Dentre os múltiplos campos artísticos existentes, o enfoque deste trabalho será o teatro, porém, pela proximidade, características e semelhanças deste campo com o da dança, da performance e da ópera, quando julgarmos pertinente ao nosso estudo poderemos nos valer de autores e exemplos destes campos irmãos para melhor exemplificar ou fundamentar um conceito.

É bastante delicado o tratamento e abordagem da Comunicação e das Relações Públicas no campo das artes uma vez que estas são manifestações e expressões culturais que constituem elemento agregador e formador de identidade de um povo. Kotler afirma que "a arte é necessária para a saúde de uma nação. Assim como a alimentação, vestuário e moradia são essenciais para o bem-estar físico, arte é essencial para a alimentação social e espiritual de nossas vidas" (KOTLER, 2007. p. VII, tradução nossa).

A arte é gerada por artistas que buscam por meio de suas obras, resultantes de um processo criativo, refletir, questionar, provocar e entreter a sociedade que habitam. Não há muitas publicações nos campos da comunicação voltadas especificamente para as artes. Assim como os estudos sobre as artes também são restritos aos seus campos específicos, cujo foco se dá nos âmbitos histórico, estético, poético do campo artístico em si, com pouca interface com outras áreas do conhecimento. Particularmente, no campo da comunicação, embora a comunicação exerça na prática uma interferência e um impacto no relacionamento entre artistas e seus públicos.

Talvez isso ocorra, pois segundo Adorno (1991) "a cultura gostaria de ser mais elevada e mais pura, algo intocável que não poderia ser customizada conforme qualquer consideração técnica ou tática". No entanto, "quem quer que fale sobre cultura, também fala sobre administração, quer seja a sua intenção ou não". (1991, p. 107, tradução nossa). 
Pode ser enriquecedor para o campo da Comunicação e das Relações Públicas ampliar o olhar e apresentar formas de implementação de políticas, estratégias e ações de comunicação e relacionamento adaptadas às peculiaridades do fazer artístico. Embora, em alguns aspectos sejam similares e sigam a lógica empresarial, em outros momentos são extremamente singulares, exigindo adaptações nas formas tradicionais de atuação.

As adaptações também devem ocorrer por parte dos artistas que estabelecem contatos e relacionamentos nos ambientes políticos e empresariais. Embora muitos artistas não aceitem e questionem a lógica do mercado, necessitam dela para a produção de suas obras. Augusto e Yanaze afirmam que:

o artista passa por um dilema: ao mesmo tempo em que, por um lado, pretende que a sua obra seja o símbolo de libertação de padrões préestabelecidos pelo sistema, portanto, contra a ordem de mercado, de consumo, do modismo, do status quo, por outro lado, necessita da própria lógica e dinâmica das leis do mercado: dos meios de produção, nos quais se permite a construção da própria obra para atender a demanda, e dos meios de divulgação, que lhe permitirão tornar pública a sua existência. Fica, portanto, dependente da lógica de mercado, ou seja, do capital econômico. (AUGUSTO; YANAZE, 2010, p. 72)

As lógicas de criação e produção artística são distintas das lógicas de produção industrial. Enquanto estas, de um modo geral, buscam dar o melhor retorno financeiro aos investidores e acionistas, aquelas buscam sensibilizar, provocar, transformar e em alguns casos até incomodar seus espectadores. A consciência dessa diferença é o que deverá conduzir as ações de comunicação e relacionamento voltados para as artes. Segundo Fonseca,

Ao atuarmos na área de cultura, estamos lidando com processos
organicamente dinâmicos, mutáveis e intangíveis, e também com
processos de criação e produção artísticas que operam numa lógica que
não é a mesma da indústria. É a capacidade de entendimento desses
processos e a sensibilidade para lidar com eles, assim como o
conhecimento sobre a cultura e as artes, que diferencia a gestão cultural
da gestão no sentido mais comum. Esta última atua mais estritamente
com processos técnico-administrativos (que por sua vez também podem
ser assumidos pela gestão cultural, ainda que readaptados ao seu
contexto). Assim como é a atuação mais estratégica, sistêmica e
ampliada da gestão cultural que a difere da produção cultural, que atua
numa esfera normalmente mais pontual e operacional, embora ambas
sejam complementares. (2011, p.2) A questão do financiamento das artes e o crescente volume de recursos que esta área representa é um tema que tem gerado estudos na área da economia, conhecidos por Economia da Cultura, dentro de uma linha mais ampla 
chamada de Economia Criativa. Segundo Machado Neto (2007), "a produção de bens culturais tornou-se muito importante para a economia e hoje são bem tênues as fronteiras entre aspectos econômicos e culturais, fazendo-se necessário refletir sobre o conjunto de forças que operam o sistema cultural e nele interagem" (p.287).

O ponto de contato entre as artes e o mercado, embora seja percebido como algo negativo e opressor por parte dos artistas, precisa ser mais bem compreendido. Segundo Tolila,

\begin{abstract}
pensar hoje a economia do setor cultural não constitui de modo algum uma derrota dos argumentos humanistas a respeito da cultura que todos conhecemos e defendemos. Não significa um abandono do terreno na luta pela defesa de um desenvolvimento cultural; significa, ao contrário, a ocupação de um terreno suplementar do qual o setor cultural e seus principais atores há muito desertaram deixando o campo livre para as pressões negativas. (TOLILA, 2007, p. 19)
\end{abstract}

Um volume considerável de dinheiro destinado à cultura provém de políticas públicas de países e regiões que alocam recursos orçamentários especialmente destinados ao fomento da cultura e das artes. No Brasil, a principal lei de incentivo à cultura é a Lei Rouanet ${ }^{3}$. Além dela há várias leis estaduais e municipais. Na cidade de São Paulo, um dos destaques neste campo é o programa de Fomento ao Teatro, em vigor desde 2002, que premia semestralmente grupos formalmente constituídos. Tolila ressalta que 0 interesse dos Estados e das coletividades públicas

manifesta-se em políticas públicas (orientações, normas e estratégias), em administrações especializadas (tanto no nível estatal quando descentralizado), em alocações de recursos dirigidos (os orçamentos culturais públicos), assim como no surgimento de numerosas instituições financiadas com dinheiro público e de um mundo diversificado de profissionais da cultura. (2007, p. 71)

Entretanto, o financiamento público não é a única forma de financiamento das artes, que também pode advir do setor privado, por meio de patrocínios de empresas ou fundações, por empreendedores ou produtores culturais que investem seus recursos próprios e pelo público que adquire ingresso para assistir a um espetáculo ou um indivíduo ou colecionador que adquire uma

\footnotetext{
${ }^{3}$ Para mais informações sobre a abrangência e critérios da Lei Rouanet acesse a página do Ministério da Cultura disponível em http://www.cultura.gov.br/site/categoria/apoio-aprojetos/mecanismos-de-apoio-do-minc/lei-rouanet-mecanismos-de-apoio-do-minc-apoio-aprojetos/informacoes-gerais-lei-rouanet-mecanismos-de-apoio-do-minc-apoio-a-projetosmecanismos-de-apoio-do-minc-apoio-a-projetos/
} 
obra de arte. Deste modo, a forma como está estruturado o financiamento da cultura faz com que os artistas necessitem estabelecer contatos regulares com ambientes corporativos, governamental e também da sociedade como um todo para viabilizar suas produções.

Pelo fato da viabilidade econômica de um espetáculo artístico advir do conjunto de fontes de recursos listados anteriormente, o equilíbrio entre as diferentes fontes de recursos varia de caso a caso. Segundo afirmam Augusto e Yanaze

como o artista, na maioria das vezes, depende de recursos financeiros para que atinja o público desejado, o primeiro passo para sua consolidação implica a constituição de um público numeroso que deseje sua obra que forme uma demanda suficiente para que ele dependa menos dos demais agentes: social (mecenas), político (governo e órgãos públicos), religioso ou econômico (empresariado). (2010, p. 72)

Como o campo artístico dos espetáculos teatrais é bastante amplo, pois há espetáculos com grande apelo comercial e de entretenimento enquanto outros são mais voltados à pesquisa artística e de vanguarda, não é possível tratá-los sob o ponto de vista comunicacional e relacional da mesma forma. Enquanto estes requerem uma abordagem adaptadas às suas características aqueles poderão fazer uso de estratégias e ações de comunicação e marketing similares às utilizadas pelas empresas.

De acordo com Cesnik e Beltrame, (2005) "a produção cultural não obedece a lógica do mercado e por isso não pode estar aprisionada a ela" ( $p$. 92). Afirmam também que "os bens culturais têm agregados valores específicos de uma sociedade, de uma época, de um modo de se referir a um contexto de forma particular, que não se reduz ao caráter anônimo e intercambiável de uma mercadoria" (CESNIK; BELTRAME, 2005, p. 94).

No que se refere ao lento desenvolvimento da Economia da Cultura, Tolila (2007) atribui a "culpa" tanto aos artistas quanto aos economistas

Como se sabe, a economia, seus cálculos e estatísticas, seus modelos e "leis" não têm boa fama nos meios culturais, que preferem opor ao mundo frio da rentabilidade, das limitações financeiras e da concorrência dos mercados, o mundo cálido da paixão, da criação livre e o valor universal dos atos culturais. Ao desinteresse dos economistas pela cultura respondeu, pois, em grande medida, pelo desinteresse dos atores culturais pela economia, suas ferramentas e seus debates. (TOLILA, 2007, p. 17-18) 
Percebe-se, contudo, que apesar dos pontos polêmicos que emergem quando se relaciona a arte ao mercado, é necessário compreender como se dá este processo da economia da cultura. Segundo Reis (2011)

essa carência patente, aliás, ocorre de modo geral no mundo, não se restringindo ao Brasil, país cujo despertar à economia da cultura é embrionário, incompleto e ainda chega a causar mal estar em alguns criadores e artistas. O receio de que a economia da cultura tenha por objetivo perverso a apropriação da cultura pelo capital, conspurcando a expressão de nossos valores mais anímicos, esmorece lentamente. (2011, p.2)

Os próprios artistas se beneficiarão ao encarar o mercado de forma clara e objetiva. Pois, complementa Reis

falar em economia da dança [teatro] pressupõe que os dançarinos [atores e atrizes], diretores, coreógrafos e demais profissionais do setor sejam entendidos - e se entendam, sem crise de consciência ou dilema moral - como agentes econômicos. Sobreviver de sua dança [seu teatro], de seu trabalho, de sua profissão, não equivale a se vender ao capital; ao contrário, não sobreviver dela [dele] condena o artista a se dedicar a qualquer outra profissão, para a qual eventualmente não tenha talento e que não the proporciona o mesmo grau de satisfação. (REIS, 2011, p.3)

Os grupos de teatro, portanto, são organizações que se relacionam e se comunicam com outras organizações, algumas delas de natureza e objetivos distintos dos seus (organizações empresariais, organizações governamentais), mas que integram um sistema mais amplo regido por "leis" explícitas e implícitas que permeiam as relações sociais, políticas e econômicas estabelecidas entre eles. 


\subsection{SINGULARIDADES DO PÚBLICO DAS ARTES}

Trazemos duas perguntas levantadas por Bernstein (2007) para referenciarmos nosso lugar de discussão: "Quais são os fatores que motivam as pessoas a frequentarem eventos ou instituições artísticas? Quais são algumas das barreiras que inadvertidamente mantêm as pessoas afastadas?" (2007, p. XIV, tradução nossa). São perguntas importantes para todos aqueles que atuam no campo artístico e são a base do trabalho dos profissionais de comunicação, relações públicas e marketing que atuam nesta área.

Estudos conduzidos por Bourdieu e Darbel, realizados na França nos anos 1963 e 1967/1968, a partir de uma amostra de 1.217 pessoas buscaram desvendar os fatores determinantes das práticas sociais dos indivíduos. Descobriram que o nível educacional dos indivíduos tem um papel relevante no apreço e na necessidade de fruição regular da arte

A observação científica mostra que as necessidades culturais são produtos da educação: a pesquisa estabelece que todas as práticas culturais (frequência a museus, concertos, exposições, leituras, etc.) e as preferências em matéria de literatura, pintura ou música são estreitamente associadas ao nível de instrução (avaliado pelo diploma escolar ou pelo número de anos de estudo), e secundariamente à origem social (BOURDIEU, 2011, p. 9).

Estudo este que levou Bourdieu e Darbel (2007) a concluírem que

Considerando que a aspiração à prática cultural varia como a prática cultural e que a "necessidade cultural" reduplica à medida que esta é satisfeita, a falta de prática é acompanhada pela ausência do sentimento dessa privação; considerando também que, nesta matéria, a concretização da intenção depende de sua existência, temos o direito de concluir que ela só existe se vier a se concretizar. O que é raro, não são os objetos, mas a propensão em consumi-los, ou seja, a "necessidade cultural" que, diferentemente das "necessidades básicas", é produto da educação (BOURDIEU; DARBEL, 2007, p. 69).

É inerente a todas as expressões artísticas a necessidade do contato com o público. E é neste ponto que as relações públicas têm total aderência às expressões artísticas, pois comunicação e relacionamento com os públicos é a natureza desta atividade (NASSAR, 2006). Os artistas, em maior ou menor grau, estabelecem contatos com os públicos, constroem relacionamentos e almejam reconhecimento pelos trabalhos realizados. Quando executam esta atividade de forma intuitiva e amadora, é provável que os esforços despendidos 
nesta ação, além de drenarem energia que poderia estar destinada ao processo criativo, necessitarão de um esforço maior sem garantias de alcançar o resultado esperado. E ao final, uma excelente obra artística poderá não conseguir estabelecer diálogo e obter reconhecimento por erros de comunicação e de relacionamento que poderiam ter sido evitados.

Segundo Barros (2007),

A competência comunicativa dos profissionais de relações públicas pode, então, potencialmente, tornar-se um meio de facilitar a interação social e não apenas a negociação de relações entre organização e seus públicos. (...) Basta considerarmos que o profissional de relações públicas é, antes de tudo, um mediador político, econômico, cultural ou comunitário, com ênfase nos dois últimos aspectos (2007, p.133).

Os grandes empreendimentos artísticos de teatro, geralmente voltados para o entretenimento, conseguem aplicar as políticas, estratégias, ações de comunicação e relações públicas tal qual elas são utilizadas pelas organizações. No entanto, para cada produção comercial ou mais voltada ao entretenimento há uma quantidade muito superior de produções de baixo orçamento, grupos jovens, amadores, alternativos, coletivos teatrais, e até mesmo grupo tradicionais que não dispõem dos recursos necessários para todas as atividades da produção teatral.

Dos espetáculos que conseguem entrar em cartaz, a grande maioria carece de uma estratégia de comunicação, marketing e relações públicas colocada em curso desde a pré-produção do espetáculo, na busca dos patrocinadores, até a divulgação da estréia e temporada do espetáculo. De modo geral, quando conseguem superar os desafios do levantamento dos recursos para financiamento da produção do projeto, o desafio seguinte será atrair espectadores para a encenação. Algumas montagens que demandaram muito esforço para serem produzidas podem acabar tendo uma temporada curta e com pouco público em função da ausência ou de uma ação inadequada de comunicação e relacionamento.

$\mathrm{Na}$ medida em que se tornam conhecidos, os artistas tendem a trabalhar junto a produtores executivos, assistentes, assessores de imprensa e comunicação. Nestes casos, as atividades de comunicação e relações públicas tendem a ser desenvolvidas de forma planejada e estruturada. 
No entanto, até chegar ao estágio de profissionalismo, se é que conseguem chegar, a maioria dos grupos geralmente carece de recursos para a execução plena das atividades de produção, comunicação e relações públicas, de forma adequada.

Em referência à comunicação, o pouco que se observa são ações clássicas voltadas à propaganda e assessoria de imprensa e mais recentemente o uso das mídias digitais, porém ainda de forma tímida e incipiente, sem planejamento ou estratégias que possam nortear uma atuação integrada.

Há uma grande discussão sobre o tipo e qualidade das manifestações artísticas que são oferecidas ao público. Não podemos nos esquecer de que o público não é homogêneo. Nem todos buscam os mesmos tipos de lazer, cultura e entretenimento. Em muitos casos, inclusive, buscam opostos. É saudável haver uma heterogeneidade de opções e alteridade de criações.

Em termos estéticos, segundo Rosenfeld "o teatro é feito para um público determinado: para a pequena burguesia, ou para a classe média, ou para estudantes, ou para operários, ou para a plateia do interior. Precisa ajustar-se a cada público quanto à forma de representação" (ROSENFELD, 2009, p. 22).

Ao abordar a questão da arte versus entretenimento, na qual as pessoas tendem a ter preferência por uma em detrimento do outro, Bernstein cita o interessante depoimento de um compositor chamado Charles Wuorinen que busca identificar os elementos diferenciadores desses estilos de obras:

Eu penso que há uma distinção muito simples, que não diminui o
entretenimento de forma alguma, porque todos queremos e gostamos do
entretenimento. O entretenimento é aquilo que uma pessoa recebe sem
esforço. Arte é algo onde é necessário fazer algum esforço, e então
você terá mais do que tinha antes. Este esforço é parcialmente resultado
de uma exposição repetida e complementado por uma ação de
educação para as artes, algo que as organizações artísticas oferecem
cada vez mais de modo mais criativo para uma audiência maior
(BERNSTEIN, 2007,p.13, tradução nossa). Avelar (2008), em seu livro O Avesso da Cena: notas sobre Produção e Gestão Cultural dedica um capítulo para o relacionamento do empreendedor cultural com o público. O livro, baseado na experiência prática, é fruto de dezenas de entrevistas com vários agentes do meio cultural. $\mathrm{O}$ autor constata a incipiência de ações voltadas às instituições culturais, especificamente 
ligadas ao teatro, em se conscientizar da necessidade de se estabelecer e construir um relacionamento permanente com o seu público. "No âmbito da cultura, entretanto, os empreendedores ainda se colocam muitas vezes numa posição distante daqueles que são a sua razão de existir. O público permanece como elemento estranho, raramente convidado a se aproximar e estabelecer uma relação de longo prazo" (AVELAR, 2008, p. 153).

Trata-se de dotar os criadores autônomos, direta ou indiretamente - por meio de agentes ou produtores - de um olhar mercadológico sobre o seu trabalho. A perda do preconceito de chamar de "produto" o, agora, produto de seu trabalho artístico. Sem a visão típica de fazer aquilo que o mercado demanda (o que é natural na indústria cultural entre seus contratados), mas de - por meio da ação desse agente - "ir aonde o povo está", numa inversão de lócus da "mercadoria-lógica", na qual o produto vai até o seu fruidor e não o contrário." (Machado Neto, 2010, p. 63)

Notamos que a literatura que aborda a questão de comunicação das artes está geralmente elaborada sob a visão e os conceitos do marketing. São publicações norte-americanas que aplicam os conceitos do marketing voltados para as artes, citando vários exemplos reais de projetos desenvolvidos por instituições artísticas. O termo comumente utilizado é Marketing for the Performing Arts.

No caso brasileiro, a literatura utiliza com frequência o termo Marketing Cultural, termo este que causa divergências e divide os pesquisadores entre os que o utilizam como sinônimo das ações de investimento e patrocínio de empresas privadas voltadas às artes e à cultura, e aqueles que o analisam como as estratégias de marketing de instituições culturais para a conquista e manutenção de seus públicos.

Se a indústria automobilística (precursora da aplicação do marketing concept) pratica um marketing automobilístico, se os laboratórios praticam um marketing farmacêutico e os bancos praticam um marketing financeiro, o setor cultural, por analogia, praticaria o marketing cultural e aí reside um dos principais problemas - até hoje - de compreensão do termo. Não se trata do marketing da indústria cultural, mas, principalmente, das práticas postas pela "ação cultural. (Machado Neto, 2010, p. 58)

O conceito acima é corroborado por Augusto e Yanaze que afirmam: "assim, marketing cultural deve ser entendido como um conjunto de ações mercadológicas na esfera das instituições culturais, em que seus produtos 
e serviços são a própria obra artística, e os fundamentos de marketing estrategicamente traçados para os seus interesses comerciais" (2010, p. 78).

Segundo Bernstein,

Diretores de marketing sempre buscam ideias para atrair mais pessoas para assistir aos espetáculos de suas organizações artísticas. Além de determinar a melhor forma de atrair público, marqueteiros também têm que aprender como quebrar as barreiras que desestimulam as pessoas a irem ao teatro. Essas barreiras são frutos das necessidades, interesses, atitudes e preferências do público, algumas podem ser influenciadas pelo marketing, outras não (BERNSTEIN, 2007, p. 16-17, tradução nossa).

O fato do processo de financiamento público e, em alguns casos, também privado de grupos e produções teatrais ser intermediado por editais de seleção que exigem uma formatação específica para a avaliação dos projetos apresentados, os grupos e profissionais de produção foram levados a desenvolver seus projetos de forma mais profissional nas fases de pré-produção, produção e elaboração do projeto artístico. No tange às estratégias e ações de comunicação e relacionamento, ainda há um longo caminho a ser trilhado pelos grupos para a incorporação dos processos de comunicação e relacionamento de forma orgânica em suas produções. Concordamos com o profissional de marketing Paulo Coelho citado por Avelar (2008) quando se refere aos artistas dizendo

Vocês fazem um esforço tremendo para captar recursos, produzir seus projetos e divulgá-los. Conquistam uma fatia de público a duras penas, mas não se preocupam em estabelecer uma relação duradoura com essas pessoas. Vocês sequer se dão ao trabalho de cadastrar aqueles que estiveram presentes em seus eventos. No ano seguinte, realizam nova produção e, mais uma vez, partem em busca de outro público. $\mathrm{O}$ antigo, já conquistado, fica para trás. É muito esforço jogado fora. (COELHO apud AVELAR, 2008, p. 155) ${ }^{4}$

Uma das questões mais delicadas no que se refere ao relacionamento dos artistas com o mercado consiste nas concessões. Segundo Bernstein, "marketing é focado no consumidor. Isso não significa que o diretor artístico de uma sinfônica, companhia de ópera, companhia de dança ou teatro deva comprometer sua integridade artística. Isso não significa apresentar mais espetáculos da Broadway e menos Shakespeare. (...) Isto significa criar uma experiência total que torna a produção mais acessível, agradável, e conveniente" (BERNSTEIN, 2007, p. 16). Acessível, agradável e conveniente não em termos artísticos, mas em termos funcionais. Oferecer uma boa estrutura de atendimento

\footnotetext{
${ }^{4}$ Palestra proferida pelo profissional de marketing Paulo Coelho em maio de 1999, no Galpão Cine Horto, em Belo Horizonte.
} 
do público previamente à apresentação do espetáculo, no processo de venda de ingressos, informações sobre o espetáculo, atendimento telefônico ou por e-mail, não representam uma ameaça à integridade artística da obra.

Sobral afirma que "parece um tabu pensar no público como se isso significasse necessariamente fazer concessões no projeto artístico. Claramente não se trata de obedecer ao senso comum, submeter-se ao mercado, popularizar a obra ou proporcionar o conforto que a indústria cultural oferece. Trata-se, antes de tudo de ser dialógico" (SOBRAL, 2011, p.5-6).

São nítidas as segmentações e até segregações de público presentes no campo das artes. "Há que se considerar que o mundo da cultura é tomado, muitas vezes, como um terreno restrito aos círculos da elite. (...) Muitos teatros, galerias, museus e centros culturais são vistos como templos sagrados e impenetráveis, privativos de uma casta intelectual e economicamente privilegiada." (AVELAR, 2008, p. 167)

Portanto, ao atuar neste campo é necessário analisar com objetividade e clareza as percepções da sociedade em relação aos diversos equipamentos culturais.

As pessoas conhecem seus gostos e normalmente não querem assumir riscos em algo que eles não conheçam. Será que eu vou gostar deste espetáculo? Irei entendê-lo? Preciso entender para gostar? Sentir-me-ei confortável lá? Eu me enquadrarei nisto? Qual a relevância que esta performance terá na minha vida? Os profissionais de marketing das artes têm que fazer um esforço para tentar entrar e entender as cabeças e os corações dos públicos das artes. Gestores que culpam fatores externos para o declínio da audiência, acreditando que o problema está fora de seus controles, são candidatos ao fracasso. Gestores que implementam estratégias de marketing apropriadas para seu público alvo estão sendo bem sucedidos. ${ }^{5}$ (BERNSTEIN, 2007,p.10)

Dentre as produções teatrais em cartaz simultaneamente em uma cidade, poucas são as que dispõem de recursos significativos de investimento em ações de divulgação e promoção dos espetáculos para atrair público

\footnotetext{
As queixas dos profissionais da área de cultura em relação à falta de público para seu empreendimento são frequentes. As grandes plateias geralmente ficam restritas aos eventos de massa, que dispõem de recursos significativos para investimento em mídia e promoção. (...) São muitos os artistas, grupos e entidades culturais que encontram dificuldade de manter regularidade de público. (AVELAR, 2008, p. 166)
}

\footnotetext{
${ }^{5}$ Texto livremente traduzido pelo autor.
} 
Nem todos os grupos e produções artísticas dispõem dos recursos e da expertise necessários para colocar em prática um plano estratégico de comunicação e relacionamento e com isso atrair o público de que necessitam para ocupar os lugares disponíveis nos teatros ou espaços de apresentação dos espetáculos.

\begin{abstract}
A trama da cultura é tecida por todos. Mas, a oportunidade de contato com os produtos culturais ainda está distante de muitos. Ao observar esse contexto, tornou-se evidente a importância de explorarmos mais intensamente 0 papel social da comunicação, utilizando seus instrumentos de mediação, a partir de suas possibilidades de aproximação entre os espectadores e as manifestações culturais. (MENDONÇA, 2010, p.106)
\end{abstract}

A Comunicação e as Relações Públicas podem oferecer aos artistas e instituições culturais oportunidades de relacionamento que vão além dos modelos clássicos de comunicação comumente utilizados via assessoria de imprensa e anúncio publicitário. Isso nos remete às origens limitadas das Relações Públicas nos Estados Unidos, a partir do trabalho realizado pelo agente de imprensa "Phineas Taylor Barum, que utilizava em seus comunicados linguagem hiperbólica, destinada a chamar a atenção dos jornalistas para seus espetáculos" (NASSAR, 2007, p. 39).

Ao longo do tempo, as Relações Públicas ampliaram o seu escopo teórico e prático. Vivemos em uma época na qual as novas mídias mídias digitais - têm um potencial de revolucionar a forma como grupos artísticos se relacionam e se comunicam com seus públicos. A mídia em si, não é nada. É necessário saber 0 que se quer comunicar com ela, quais mensagens, informações e conteúdos transmitir. E uma das principais fontes de conteúdo está justamente naquilo que é único de cada indivíduo, de cada grupo. Sua identidade, suas realizações, sua história, sua memória. Elementos fundamentais para a constituição e construção de imagem e de reputação institucional.

Direcionaremos, a partir de agora, nosso olhar de modo mais aprofundado à história e às especificidades do teatro, seus suportes de registro e como este material pode ser utilizado para multiplicar a oportunidades de contato e comunicação entre os grupos de teatro e seus públicos. 


\section{O PARADOXO DA MEMÓRIA DO TEATRO}

Os textos mais antigos do teatro ocidental acessíveis hoje em dia são eles próprios frutos de uma forma de registro e documentação, neste caso, por meio da escrita. Os concursos de tragédias dedicadas a Dioniso, deus do vinho, premiavam os vencedores com o registro de seus textos. Pisístrato, tirano de Atenas, foi o fundador das Grandes Dionisíacas ou Dionisíacas Urbanas, festividades públicas nos âmbitos artístico, intelectual e religioso em Atenas onde havia competições teatrais conhecidas por agon. "O prêmio concedido era uma coroa de louros e uma quantia em dinheiro nada desprezível (como compensação pelos gastos anteriores), e a imortalidade nos arquivos do Estado. Esses registros (disdascália), (...) listam o nome dos coregas, os dramaturgos vencedores de prêmios, juntamente com os nomes das tetralogias, vencedoras do concurso final" (BERTHOLD, 2004, p. 113).

Dos cerca de 290 textos que se acredita terem sido escritos pelos três principais dramaturgos da tragédia grega (Ésquilo, Sófocles e Eurípides) apenas 22 tragédias conseguiram vencer a batalha do esquecimento. Consta que Ésquilo escreveu noventa tragédias, das quais se conhecem 79 títulos, porém estão preservados os textos de apenas sete peças. O mais antigo texto teatral grego que se tem acesso é de sua autoria. A tragédia Os persas data de 472 a.C.. Sófocles escreveu 123 tragédias, que estavam arquivadas na Biblioteca de Alexandria até o século II a.C. Conhecem-se 118 títulos, porém preservaram-se apenas sete tragédias e restos de uma sátira. Já de Eurípides se conservaram 17 tragédias e uma sátira das 78 obras escritas. Estas tragédias ainda são encenadas e seus temas influenciaram e influenciam inúmeros pensadores, criadores, artistas e pesquisadores. O processo do registro dos textos teatrais por meio da escrita permitiu o surgimento de um arcabouço de conhecimento artístico, filosófico, psíquico sobre o homem e a humanidade de importância incontestável. 
Embora muito importante, a memória do teatro não se restringe à preservação da integridade dos textos escritos, sendo esta apenas uma de suas dimensões.

Como (e o que) pode preservar-se de uma arte que, fazendo apelo a todas, é por natureza efêmera e volátil? O texto, sem dúvida - "as palavras que são o corpo da peça", como dizia Gordon Graig -, mas sem que de modo algum se esgotar, sob pena de ser apenas um segmento da história da literatura, onde aliás, ocupa um lugar subalterno, salvo em relação aos grandes nomes, os trágicos gregos, os dramaturgos isabelinos e da França de Luís XIV, Goethe ou Goldoni, Ibsen ou Strindberg, mais recentemente Pirandello, Brecht e Beckett, ou entre nós Gil Vicente e Garrett... Mas até os textos constituem um material precário, movente, submetido às contingências da representação e da sua recepção pelo público, que variam com as épocas e as coordenadas sociais. E que só atingem o seu pleno significado e cumprem integralmente a sua função quando se opera a metamorfose do verbo em acto e o público dela participa, assim com o a partitura de uma sinfonia quando é executada ou o projeto arquitectónico de uma casa quando é construída. Ou a semente quando germina. (REBELLO, 2005, p. 10-11)

Mesmo em encenações que utilizam os textos na íntegra, embora os artistas tenham autonomia para mexer no texto, a recepção que a peça receberá será distinta daquela que a encenação original recebeu. Tanto os criadores como os públicos enxergarão a encenação através de filtros históricos e sociais que agregarão ao texto original novas leituras, interpretações e significados.

\begin{abstract}
A história do teatro europeu começa aos pés da Acrópole, em Atenas, (...). Suas origens encontram-se nas ações recíprocas de dar e de receber que, em todos os tempos e lugares, prendem os homens aos deuses e os deuses ao homem: elas são rituais de sacrifício, dança e culto. Para a Grécia homérica isso significava os sagrados festivais báquicos, menádicos em homenagem a Dioniso, o deus do vinho, da vegetação e do crescimento, da procriação e da vida exuberante. Seu séquito é formado por Sileno, sátiros e bacantes. Os festivais rurais de prensagem do vinho, em dezembro, e as festas das flores de Atenas, em fevereiro e março, eram dedicados a ele. As orgias desenfreadas dos vinhateiros áticos honravam-no, assim como as vozes alternadas dos ditirambos e das canções báquicas atenienses. Quando os ritos dionisíacos se desenvolveram e resultaram na tragédia e na comédia, ele se tornou o deus do teatro. (BERTOLD, 2004, p. 103)
\end{abstract}

Com o passar dos anos, das décadas, dos séculos e dos milênios formas complementares e mais sofisticadas de registro foram incorporadas ao registro textual. Tais como pinturas e desenhos de cenas, de atores, de autores, tendo um grande salto na multiplicação desses documentos no final do século $X I X$, e principalmente nos séculos $X X$ e XXI com o advento de suportes de registros de maior reprodutibilidade e com possibilidade de captar mais 
dimensões da cena como a fotografia, a gravação do áudio, a gravação em filme ou vídeo para TV, cinema ou internet, geraram uma série de materiais que documentam e registram espetáculos e processos criativos das artes cênicas de forma mais ampla e diversificada. Embora nenhum método de preservação do teatro seja completo. Esses tipos de materiais são as principais fontes de informação que os estudiosos e pesquisadores utilizam em suas pesquisas.

Sendo o berço do teatro ocidental a Grécia, não é coincidência que as musas que regem o teatro sejam filhas da deusa da memória.

\begin{abstract}
Melpómone e Tália, musas da tragédia e da comédia, eram, segundo a mitologia grega, filhas de Zeus e de Mnemósine, a deusa da memória. A elas e às suas sete irmãs um templo foi consagrado, a que se deu 0 nome de Museu. Pode supor-se que os compartimentos desse templo fossem destinados - por obediência à progênie materna - a perpetuar a memória das artes (e das ciências) que tinham como fonte inspiradora cada uma das nove musas. (REBELLO, 2005, p. 9)
\end{abstract}

Ao visitar um museu, especialmente os dedicados às artes visuais, artes plásticas ou belas artes, o visitante tem contato direto com obras originais realizadas há séculos, milênios. Quem vê a Monalisa, está diante do quadro original pintado por Leonardo Da Vinci, quem entra na Capela Sistina, observa o projeto executado por Michelangelo, quem vai ao Egito se depara com as pirâmides construídas há milhares de anos.

O que mais se aproxima dessa experiência no teatro é a visita aos lugares, construções ou edifícios de teatro e anfiteatro, em diferentes estados de preservação, existentes em diversas cidades da Europa, mas principalmente na Grécia e Itália: o Anfiteatro de Epidauro e o Teatro de Mileto, na Grécia; o Teatro Romano de Verona e o Teatro Romano de Fièsole, na Itália. Também na Itália há - Teatro Olímpico de Vicenza, considerado o edifício teatral coberto mais antigo que existe. Um segundo atrativo histórico neste teatro é a permanência do cenário original da primeira peça apresentada em seu palco, em 1585.

Estão em pleno funcionamento diversos teatros de importância histórica. Muitos desses teatros são dedicados à Ópera e ao Balé nas principais cidades do mundo. Recentemente no Brasil houve a comemoração do centenário de dois de seus principias teatros: o Theatro Municipal de São Paulo e o Theatro Municipal do Rio de Janeiro. Alguns teatros foram destruídos pelo fogo, e, posteriormente, restaurados ou reconstruídos, com é o caso do Globe Theater em 
Londres e o Teatro La Fenice, em Veneza. Nestes teatros, o rigor e a precisão utilizados em suas reconstruções são indícios da importância dada às questões de preservação e memória das artes. Tornam-se inclusive pontos de atração turística.

A experiência de ir a ou visitar um teatro antigo de valor histórico significativo é apenas uma das múltiplas possibilidades de contato com elementos e vestígios da memória do teatro. No caso das artes cênicas, o acesso aos vestígios da memória dos espetáculos é mais complexo, ainda que existam museus dedicados exclusivamente ao teatro, à dança e à performance.

Podemos destacar o Museu Nacional do Teatro de Lisboa; a coleção de teatro do Victoria \& Albert Museum de Londres que é composta também por um acerco de teatro filmado dos espetáculos realizados naquela cidade e que podem ser consultados na Blythe House Archive \& Library Reading Room mediante agendamento prévio; o Museu da Dança de Estocolmo; os acervos da New York Public Library for the Performing Arts, que se dividem na Billy Rose Theatre Division e no arquivo de teatro filmado (TOFT - Theater on Film and Tape Archive); o Centro de Pesquisa e Memória do Teatro, do Galpão Cine Horto em Minas Gerais; o Museu do Theatro Municipal de São Paulo e o Centro de Produção Chico Giacchieri do Theatro Municipal de São Paulo, que contém o figurino e restos de cenário de espetáculos apresentados nesta instituição artística, a divisão de pesquisas do Centro Cultural São Paulo que sucedeu o antigo Idart - Departamento de Informação e Documentação Artística, - Centro de Estudos e Memória do Teatro Paulista dentro do Arquivo do Estado de São Paulo para citar alguns exemplos.

Ao tocar a questão sobre os museus de teatro, Melo afirma,

Quase nada sabemos, nada respondemos, tudo se foi, conjecturamos, documentamos. E de muito teatro nada, nada mesmo ficou, nem retrato, nem programa, nada. Sobretudo do menos institucional, do mais esporádico que, lá por ser aos arremessos, não é menos teatro e teve coragem nas pernas.

Tendo assim os museus de teatro a guardar mais a memória das instituições do que a memória dos espetáculos, (...) é mais frequente neles encontrarmos os resquícios dos mais ricos, perdidas que foram as experiências mais inovadoras, forçosamente marginais. (MELO, 2005, p. 15) 
Em função do dinamismo e multiplicidade de leituras e interpretações que um espetáculo ou uma obra permite, essas instituições de preservação da memória do teatro cumprem um papel e uma função importante na perpetuação da memória das artes cênicas, porém geralmente limitadas aos grupos mais reconhecidos e já institucionalizados. As exposições dos museus tendem a apresentar um panorama mais geral da história do teatro do que aprofundar em algum espetáculo ou processo criativo específico.

Pois se quando o pano cai, ainda o actor não entrou em seu camarim para despir a personagem, ainda o público não abandonou a sala, e já da representação, da arte do teatro, nada mais existe senão aquilo que a memória guardou e o esquecimento acabará por vencer, como é possível que este momento, essa arte de natureza tão fugidia como o próprio tempo, possa ser capturada em um museu? É na vibração em conjunto entre o actor e o público que reside na força do Teatro. É na efemeridade dessa vibração que reside a fraqueza do Teatro. Mas se tal vibração, pouco a pouco, se esbate na memória, coisas existem que podem, por momentos, torná-la viva, calorosa, quase presente. Coisas, por vezes, olhadas de pouca importância: um programa, uma fotografia, o som de uma música, talvez um simples bilhete de entrada ou um recorte de jornal. São vestígios do Teatro. (SANTOS, 2005, p. 31-32)

Os níveis de interesse por estes tipos de materiais variam de acordo com os usos que os públicos farão. Há o interesse acadêmico de pesquisadores cujo objeto de estudo se relaciona à história do teatro, ou especificamente, à trajetória de algum autor, ator ou atriz, encenador, cenógrafo, figurinista, grupo de teatro, enfim todos os agentes integrantes de uma produção cênica.

Há também o público espectador que poderia ter acesso a uma série de materiais que existem, mas, por falta de recursos, falta de conhecimento, falta de informação ou falta de um projeto de memória dos grupos de teatro acabam ficando à margem no acesso aos materiais de natureza histórica e memorial dos grupos e de seus processos criativos. rata-se de um público numeroso e essencial para a viabilização dos espetáculos.

Se o tal momento mágico, a vibração em comum, não se pode captar, todos os vestígios ajudam a prolongá-lo. Antes da representação existem já as maquetas dos cenários, os figurinos, depois o guarda-roupa e os adereços de cena, o texto marcado pelo encenador, anotados pelos actores e pelo ponto, o cartaz, o programa, o bilhete de entrada e tantas coisas mais. Depois das representações existem as críticas, os anúncios, as crônicas, as caricaturas ou desenhos, as músicas, as cartas, os postais, as mais variadas lembranças e, claro, as indispensáveis fotografias. Mais recentemente, talvez, até uma gravação em vídeo do próprio espetáculo. 
Nada disso pode captar o momento mágico que é o Teatro, mas o Teatro

está presente em tudo isso. (SANTOS, 2005, p. 32)

Apesar de ser impossível o registro do teatro de forma integral, pois cada apresentação é única, os vestígios oriundos dos espetáculos e dos processos criativos são elementos que reunidos e trabalhados de forma pensada e articulada cumprem a função de prolongar, ainda que forma incompleta, a memória desses momentos passageiros.

\subsection{TEATRO: ENTRE O EFÊMERO E O PERPÉTUO}

A principal característica que distingue as artes cênicas dos outros tipos de arte é a presença concomitante do público com o que é representada. Um mesmo tempo e um mesmo espaço são compartilhados pelo criador ou criadores artísticos e pelo seu público. O espectador tem um único tempo para absorver o que está sendo apresentado. Sem isto, não há teatro. "As performances teatrais requerem tempo para suas apresentações. As performances teatrais requerem tempo para suas recepções. $O$ tempo que uma performance é recebida pela sua audiência é o mesmo tempo em que ela é apresentada" (HAMILTON, 2006, p.221 tradução nossa).

Segundo Lehmann,

para o teatro, a questão é sempre o tempo vivido, a vivência temporal que atores e espectadores partilham e que evidentemente não é mensurável com exatidão, mas apenas experimentável. A análise e a reflexão acerca do tempo teatral dizem respeito a essa experiência, que Bergson distinguiu do tempo objetivável e mensurável como "duração" (durée). Quando não se pode realmente mensurar, convém ao menos elaborar distinções conceituais. O objetivo da análise do tempo no teatro pós-dramático não pode ser o de estabelecer os pontos observáveis de descrição, mas o de diferenciar os níveis de experiência temporal nesse teatro de modo a contribuir para a compreensão da temporalidade das artes. (LEHMANN, 2007, p.287)

A questão da temporalidade, da efemeridade é um dos principais pontos que distingue as artes cênicas, o teatro, dos outros tipos de arte. Conforme argumenta Alvarez (2005),

o que diferencia as artes do espetáculo das outras artes, que produzem uma obra que perdurará através dos tempos (uma pintura, uma escultura), é o seu caráter efêmero - produz-se algo para desaparecer de seguida (o espetáculo de teatro), e o que se produz é resultado, não do trabalho individual, solitário, do artista, mas antes de uma equipe especializada em muitas artes e saberes sendo, portanto, produto de 
vários processos criativos (o escritor, o cenógrafo, o encenador, o actor, o músico, o luminotécnico, etc.) (2005, p. 6)

O termo teatro pode ser entendido como uma série de agentes, ações e atividades distintas, tais como: texto/ dramaturgia; diretor; ator; cenógrafo; figurinista; maquiador; iluminador; sonoplasta; produtor; sala/ espaço para encenação. Grupos ou Companhias de teatro são constituídos formalmente e ao longo do tempo produzem uma série de espetáculos, constituindo assim um repertório artístico.

Sobre os conceitos atribuídos à palavra teatro, Rebello complementa

A palavra "teatro" cobre conceitos diversos, que remetem para realidades diversas. Diz-se "o teatro de Shakespeare, de Gil Vicente e Santareno", o teatro romântico, o teatro simbolista", "o teatro renascentista", para significar o conjunto da obra dramática (consistente numa sequência textual de réplicas e didascálias) escrita por um determinado autor, filiada numa determinada tendência estética, criada numa determinada época. Mas, nestas duas acepções, será também o conjunto das representações teatrais (texto e espetáculo, aliás uma falsa dicotomia) integradas nessa tendência, nessa época. E "teatro" é ainda o edifício onde a representação tem lugar (o Globe Theatre, a ComédieFrançaise, o Teatro D. Maria II) ou , mais restritamente, no interior desse edifício, o palco, o espaço que a representação acontece: o teatro representa um salão, um jardim, um claustro," lia-se com frequência na didascália inicial de muitas peças do século XVIII. Finalmente, é teatro a própria prática teatral, a representação de um texto por actores sobre um palco diante de um público. Destas várias acepções, a última, é sem dúvida a mais abrangente, a que melhor corresponde à especificidade do teatro como categoria artística que ele é. (2005, p. 9-10)

Embora, ao longo do nosso trabalho, utilizamos inúmeras vezes os termos artes cênicas ou teatro, sabemos que eles não conseguem representar todos os tipos de manifestações artísticas de características efêmeras existentes.

A essa multiplicidade de métodos e pontos de vista acrescenta-se a extrema diversidade dos espetáculos contemporâneos. Não é mais possível reagrupá-los sob um mesmo rótulo, mesmo sendo um tão complacente como "artes do espetáculo", "artes cênicas" ou "artes do espetáculo vivo". Está concernido tanto no teatro de texto (que encena um texto preexistente) como o teatro gestual, a dança, a mímica, a ópera, o Tanztheater (dança-teatro) ou a performance: exemplos de manifestações espetaculares que são produções artísticas e estéticas. (PAVIS, 2005, p. XVIII)

A revolução tecnológica digital pela qual passamos atualmente amplia o espaço de divulgação para todos aqueles que desejam abrir um novo canal de diálogo e relacionamento com seus públicos. Este canal precisa ser preenchido por informações, mensagens e conteúdos, pois se não houver 
atualização permanente a eficácia deste canal ficará comprometida e ao invés de agregar valor ao grupo, poderá prejudicá-lo.

Um dos tipos de conteúdo que podem alimentar estes canais são textos, imagens e/ou vídeos de processos de criação em andamento ou espetáculos já realizados. Ou seja, documentos que o grupo já possui ou que podem ser captados já com a finalidade principal de veiculação nas mídias digitais do grupo e relacionados à sua história e memória.

Se, no passado, eram escassas as oportunidades de inserção nas instituições formais como museus e arquivos, de materiais de muitos grupos teatrais por ainda não terem um reconhecimento institucional representativo, o cenário atual permite que os próprios grupos possam escolher os materiais que desejam tornar públicos e os meios e suportes que desejam utilizar. Com isso, estarão trabalhando para o fortalecimento de sua reputação e construção de uma narrativa própria.

Projetos de memória dos grupos de teatro permitem múltiplas utilizações do material gerado. Desde ações de divulgação a processos de reflexão como possibilidade de transformação criativa. Nota-se isto nos princípios norteadores do projeto de memória da Companhia do Latão: "Ao completar dez anos de existência, a Companhia do Latão deu início a um projeto de organização da memória do grupo, com o objetivo de mapear, reunir e divulgar sua produção e estabelecer as bases para a renovação da sua pesquisa artística". (URBINE, 2009, p. 137)

Há uma série de grupos que estão trabalhando a sua história e suas memórias e projetos de memória estruturados. Entretanto, apenas o projeto estruturado não basta. É importante acompanhar como este material está sendo disponibilizado ou tornado público.

A revolução tecnológica que ampliou a digitalização e a virtualização do mundo confronta as artes cênicas naquilo que lhe é mais peculiar, a comunhão entre o público e os atores num mesmo espaço e ao mesmo tempo. Os projetos de memória desenvolvidos pelos grupos de teatro criam oportunidade de acesso a partes desses momentos e experiências por meio de uma série de produtos gerados pelos próprios grupos de teatro destinados ao público se 
materializam e se manifestam nos seguintes formatos: livro histórico, livro com o texto das apresentações, DVDs documentários da história do grupo, DVDs com o registro de uma das apresentações de um espetáculo, exposições de fotos e objetos do grupo, sites e blogs na internet, arquivos, centro de documentação e memória, e re-encenação de espetáculos; mostras de repertório. Estes projetos normalmente intensificam-se quando os grupos aproximam-se de uma data comemorativa, e desejam aproveitar estes momentos de celebração para registrar e perpetuar suas histórias e memórias no meio artístico e cultural. Com isso, passam a emitir um posicionamento crítico e analítico, além de ocupar um novo espaço e trabalhar ativamente na construção das suas próprias narrativas.

Sabemos, no entanto, que os recursos dos grupos de teatro são, na maior parte das vezes, escassos. Ao escolher investir esse tempo, dinheiro e pessoas, transferindo "energia" que poderia ser destinada à produção artística strictu senso para os projetos de memória, os grupos reconhecem a importância desta ação para o fortalecimento e perpetuidade de suas ações e posicionamentos artísticos. Essa ação contribui para a construção de uma narrativa baseada na experiência e elaborada pelo próprio grupo, cuja intenção é declarar um posicionamento sobre a forma como o grupo se enxerga e deseja ser percebido pelos públicos.

Ao olhar o escopo das pesquisas e práticas relacionadas ao tema da Memória Institucional nota-se um predomínio de exemplos de empresas e instituições ligadas à produção de bens e serviços (NASSAR, 2006a). Entretanto, ao ampliar este olhar de modo atento, percebe-se um movimento concomitante também no campo artístico, em especial no campo das artes cênicas, como os produtos gerados ou projetos de memória dos seguintes grupos teatrais: Grupo Galpão (MG); Oi Nóis Aqui Traveiz (RS); Armazém Cia do Teatro (RJ); Cia do Latão (SP); Teatro da Vertigem (SP); Grupo Folias (SP); Teatro Oficina Uzyna Uzona (SP); Lume (SP); Grupo Sátyros (SP); Grupo XIX (SP); Cia dos Atores (RJ); Grupo Officina Multimédia (MG); Ornitorinco (SP); Asdrúbal Trouxe o Trombone (RJ) e Pod Minoga (SP). Além dos grupos, festivais de teatro (Festival de Teatro de Curitiba, Festival Internacional de Teatro de Londrina) e espaços de 
teatro (Alfa, TUCA, Theatro Municipal de São Paulo) que também desenvolvem ou desenvolveram projetos ou produtos de preservação de sua memória.

Observa-se recentemente $\mathrm{o}$ surgimento de iniciativas $\mathrm{e}$ experiências cênicas que fazem uso das novas tecnologias, as tecnologias digitais que permitiram a encenação de espetáculos por meio da internet e/ou projeções, rompendo com o paradigma canônico da necessidade da presença física dos atores e público em um mesmo espaço, ao mesmo tempo para a viabilização de uma ação teatral.

Uma dessas novas propostas é o espetáculo Os Cegos, da UBU - Cia. de Criação, de Montreal, Canadá, apresentado no SESC Pinheiros em São Paulo entre os dias 29 de julho a $1^{\circ}$ de agosto de 2010. Por meio de uma tecnologia especial, os atores não estavam presentes fisicamente na encenação. Nesse espetáculo eram utilizadas projeções em alta definição dos rostos dos artistas e em função da iluminação e disposição dos elementos no palco transmitia-se a impressão de que os atores estivessem ali.

Outra possibilidade são os espetáculos da companhia Teatro Para Alguém, criada em 2008. Sua proposta artística é criar peças de teatro pensadas originalmente para internet. São quase 40 peças que foram transmitidas ao vivo e que permanecem disponíveis para serem assistidas a qualquer hora, de qualquer lugar. Também na plataforma da internet, o site Cennarium ${ }^{6}$ transmite na íntegra peças pré-gravadas. Em julho de 2011, o acervo era composto por 75 espetáculos.

Cada vez mais as apresentações de espetáculos em alta definição (High Definition - HD) de instituições artísticas como o Metropolitan Opera House de Nova lorque, o National Theatre de Londres e o Ballet Bolshoi, de Moscou, são transmitidas ao vivo e também versões pré-gravadas para cinemas ao redor do mundo.

Este cenário em que se configura as novas possibilidades de apreciação das artes cênicas, que rompem com uma tradição milenar de atores e

\footnotetext{
${ }^{6}$ Para mais informações acesse http://www.cennarium.com/
} 
espectadores, num mesmo espaço, ao mesmo tempo, necessita de estudos específicos para qualificá-los, como essas obras, esses registros se relacionam com a obra "original".

Partiremos agora para a análise aos principais suportes e tipos de registros e documentação do teatro. Por meio do texto e da imagem fixa ou em movimento, nas suas formas impressa, eletrônica ou digital, identificaremos possíveis usos, limitações, possibilidades desses vestígios que materializam e estendem os momentos de comunicação e relacionamento entre os grupos de teatro e seus públicos. 


\title{
4. VESTÍGIOS DO TEATRO
}

No mundo das artes, a autenticidade das obras é uma questão fundamental e relevante. Com o advento das novas tecnologias e suportes de reprodução, um indivíduo é impactado por milhares de imagens diariamente, sendo muitas delas imagens de reprodução de obras de arte, quer por meios impressos, eletrônicos e digitais. Benjamin (1994) em seu estudo sobre a obra de arte na era de sua reprodutibilidade técnica coloca a questão em discussão embora reconheça que "mesmo na reprodução mais perfeita, um elemento está ausente: o aqui e agora da obra de arte, sua existência única, no lugar em que ela se encontra" (p. 167). Em alguns tipos de arte como a fotografia e o cinema, a questão da reprodutibilidade está imbricada em seu próprio processo produtivo. Porém, no caso das artes cênicas, ocorre o oposto, e

\begin{abstract}
a arte contemporânea será tanto mais eficaz quanto mais de orientar em função da reprodutibilidade, portanto, quanto menos colocar em seu centro a obra original. É óbvio, à luz dessas reflexões, por que a arte dramática é de todas, a que enfrenta a crise mais manifesta. Pois nada contrasta mais radicalmente com a obra de arte sujeita ao processo de reprodução técnica, e por ele engendrada, a exemplo do cinema que a obra teatral, caracterizada pela atuação sempre nova e originária do ator. (BENJAMIN, 1994, p. 180-181)
\end{abstract}

Por este motivo é importante ressaltar que quando nos referimos aos registros das encenações de teatro, em momento algum acreditamos que estes materiais possam substituir ou até mesmo se aproximar da experiência de assistir ao espetáculo presencialmente.

Por outro lado, este tipo de material existe e está cada vez mais próximo e acessível ao público. Qual o efeito então que este material gera no público? Como este material se relaciona, dialoga com a obra original? Será que a peça pode se metamorfosear em outros suportes, em outras mídias? Não se trata mais do espetáculo, mas de outra obra, que se origina a partir de um ponto determinado e reconhecível, um espetáculo teatral, este sim efêmero e irrepetível.

Nem todos esses registros podem ser tratados de forma secundária, apenas como um simples desdobramentos da obra artística original, Há casos em que estes materiais são gerados como uma obra artística em si. Por exemplo, as fotos de Freedi Kleeman e Lenise Pinheiro que abordaremos em seguida se enquadram neste perfil. Também as filmagens que o documentarista 
Evaldo Mozarzel realizou dos Espetáculos BR-3 do Teatro da Vertigem, que gerou a filmagem da peça e um documentário sobre o processo criativo, além das filmagens realizadas de outros grupos da cidade de São Paulo.

Em um texto focado na questão da reprodutibilidade da dança, mas que pode ser empregada também para o teatro, Kopp afirma,

\begin{abstract}
A dança é, com pequenas restrições, a mais difícil das artes para se documentar. Uma tradição vinda de geração em geração, do professor ao aluno, de dançarino a dançarino, a arte efêmera deixa poucos registros tangíveis: impressos e gravuras das performances, algumas anotações, críticas, representações iconográficas, fotografia, talvez alguns filmes e vídeos, rascunhos de como as performances pareciam. (KOPP, 1995, p. 10, tradução nossa).
\end{abstract}

Embora "nenhum método de preservação da dança seja

completo, (...) registros de documentação tipicamente incluem: programas; clipping de notícias; cartazes; fotografias; caderno de anotações; vídeos; filmes; gravações de áudio; desenhos do figurino e do cenário; entrevistas em história oral; correspondências" (KOPP, 1995, p. 10, tradução nossa).

Dentre as múltiplas possibilidades de tipos de registros que se tem acesso, ou que podem produzidos pelos próprios grupos, escolhemos abordar três possibilidades distintas em nosso estudo. A fotografia, os livros históricos e as filmagens dos espetáculos.

\title{
4.1 FRAGMENTOS DE CENAS
}

Ao buscar referências sobre a fotografia de espetáculos teatrais, grupos de teatro, atores e atrizes, diretores, figurino, cenografia, iluminação teatral no Brasil, encontramos dois fotógrafos que se destacam pela regularidade e tempo de registro desta cena: Fredi Kleemann e Lenise Pinheiro.

É tido como pioneiro neste campo o fotógrafo e ator Fredi Kleemann. Alemão, nascido em 1927, aos seis anos emigra para o Brasil e em 1949, o então funcionário da empresa Fotóptica é convidado por Cacilda Becker para fazer parte do Teatro Brasileiro de Comédia - TBC. Kleemann passa a ser o fotógrafo oficial do TBC e quando Cacilda deixa o TBC para fundar a sua própria companhia de teatro, Kleemann a acompanha. Registrou também espetáculos de outras companhias até o ano de 1973. Kleemann faleceu no ano seguinte, 
deixando um acervo, composto por cerca de 12.000 negativos adquiridos pelo IDART - atual divisão de pesquisas do Centro Cultural São Paulo, e está disponível para consultas.

Em 1991, a Secretaria Municipal de Cultura do São Paulo editou um livro com fotos de Kleemann intitulado Foto em Cena e em fevereiro de 2009 foi realizada uma exposição de suas fotos no Centro Cultural São Paulo. Pode-se afirmar que as suas fotografias são o principal registro visual do TBC e da Companhia de Teatro Cacilda Becker. Segundo Décio de Almeida Prado, "as fotos de teatro tiradas por Fredi Kleemann têm sido muito utilizadas como documentos, testemunhos de um período e de um modo de representar que já desapareceram, deixando poucos vestígios tão valiosos quanto esses" (PRADO, 1991. p.1).

Em 2008, foi lançado o livro Fotografia de Palco, reunindo quinhentas e sessenta e sete (567) fotos compreendendo um período de 25 anos de trabalho da fotógrafa Lenise Pinheiro. Nesse período, Lenise registrou mais de 115.000 imagens. Os primeiros trabalhos de destaque da fotógrafa foram os registros dos espetáculos do encenador José Celso Martinez Corrêa no início da década de noventa.

Em 1998, passou a colaborar regularmente para a imprensa no jornal Folha de S. Paulo. Foi necessário adaptar o seu estilo à linguagem do jornal. Em dezembro de 2007, cria com o jornalista Nelson de Sá o blog Cacilda que posta semanalmente fotos de espetáculos teatrais atuais. Assim como Kleemann, Lenise não se restringe apenas ao ato de fotografar o teatro.

No início do livro, Pinheiro (2008) registra que o mesmo é inspirado em Fredi Kleemann. Há quem diga que ela é sua herdeira natural, porém, já na apresentação, Danilo Santos de Miranda revela a principal distinção do trabalho de ambos conforme o trecho a seguir: "mas, e o teatro de palco? Onde encontraria seu registro peculiar e fiel? Ora, na fotografia especializada, na arte paciente e inspirada desses artistas que constroem suas obras a partir do instinto e do talento dos outros. Fredi Kleemann buscou o retrato. Lenise busca 0 instantâneo não elaborado" (MIRANDA, 2008 p. 13). 
A fotografia de teatro não pode e nem deve ser vista apenas como um documento de registro da realidade, no caso, de uma representação da realidade. Ou seja, a representação da representação da realidade. Pois ela também é uma obra artística. No prefácio do livro de Fredi Kleemann, o crítico Décio de Almeida Prado comenta algumas questões importantes no modo de contemplar as fotos de teatro. São quatro parágrafos não simultâneos, mas que agrupados linearmente nos orientam para analisar e interpretar as fotografias de teatro e estão transcritos a seguir:

No que se refere ao aspecto estético percebeu-se logo que a nova arte (fotografia) não considerava a realidade senão como pretexto, um ponto de partida para criações pessoais, que traziam sempre a marca do artista, nunca valendo somente pela fidelidade do real. Mais ainda: essa sonhada fidelidade manifesta-se inexequível, pois o próprio ato de encará-las através de uma objetiva modifica as coisas. $\mathrm{O}$ mesmo rosto não é exatamente o mesmo visto de cima ou de baixo, da esquerda ou da direita.

(...) Agora, por um dever elementar de justiça - e de justiça poética - pretende-se o contrário: que estas fotografias sejam contempladas em si mesmas e por si mesmas, pelo que são e não pelo que significam como reflexos de outras realidades, humanas ou artísticas. Pede-se ao leitor, em outras palavras, que veja o que está diante de seus olhos, sem buscar por trás o Teatro Brasileiro de Comédia ou o Teatro Cacilda Becker - as principais, porém não únicas, fontes em que Fredi se abeberou.

(...) Claro está que persiste sempre um hiato entre a representação cênica, arte do movimento, desenrolada tanto no tempo quanto no espaço, e a imobilidade fotográfica. Porém, mesmo assim, a série de instantâneos (no sentido de que toda fotografia capta um só instante) quando somado, restitui-nos, se não o desempenho dos atores, ao menos a atmosfera artística que os cercava, evocando sugestivamente uma parcela do que foi vivido por uma geração inteira e que, sem essa espécie de aide-mémoire gráfica, ficaria ainda mais perdido entre vagas recordações.

(...) Esperança de que esse teatro afinal tão transitório quanto os outros sobreviva de algum modo no tempo ao se transformar em arte puramente espacial. $O$ teatro passa, a fotografia fica - eis, resumida, a filosofia banal e para mim um tanto melancólica que se tira deste bem pensado e involuntariamente nostálgico volume. (PRADO, 1991, p.1-4) 
A partir deste posicionamento de Décio de Almeida Prado podese observar e interpretar as fotografias de teatro seguindo caminhos paralelos e sobrepostos:

1. O que as fotografias são (o que está diante dos olhos);

2. O que as fotografias significam (a atmosfera artística sugerida na imagem);

3. A fotografia enquanto documento e registro do passado, elemento de preservação da memória do efêmero;

4. A fotografia enquanto objeto estético e artístico em si.

Lembrando sempre que a fotografia é apenas um fragmento. $\mathrm{O}$ teatro é efêmero e a forma como ele se perpetua no tempo é por meio dos registros, documentos, textuais e visuais. "E o que dizer da fotografia de cena, onde se cruza (como uma espécie de espelho do espetáculo propriamente dito) o trabalho de múltiplos criadores: desde logo, o do fotógrafo, depois, o do encenador, o do ator, o de quem para ele e para a cena desenhou, ou do dramaturgo que tudo aquilo inventou?" (ALVAREZ, 2005, p. 7) Ao mesmo tempo, o trabalho do fotógrafo vai além de um trabalho de documentarista, pois ele é também um artista. A imagem que observamos passa pelo filtro de seu olhar, sua estética, sua subjetividade.

No prefácio do livro de Lenise Pinheiro, Otávio Frias Filho comenta que "a fotografia no teatro costuma ter objetivo documental. Mas quando o fotógrafo trabalha como artista, ele se lança na perseguição daquele lapso de tempo em que o acontecimento teatral pode ser retido como uma borboleta, presa na rede, que logo a seguir se soltasse" (FRIAS FILHO, 2008. p.14).

Vale citar também o depoimento da cenógrafa Daniela Thomas no livro da Lenise: "o que restou da maioria dos espetáculos para os quais desenhei e construí cenários e figurinos foram as fotos da Lenise. Minha memória está completamente imbricada no olhar dela, daí que não me lembro do que vi ou do que vi Lenise vendo" (PINHEIRO, 2008, p. 227). 
A fotografia é um dos elementos de perpetuação da memória conforme afirma Bóris Kossoy em seu livro Os tempos da fotografia: o efêmero e o perpétuo

A perpetuação da memória é o denominador e, de uma forma geral, o denominador comum das imagens fotográficas: o espaço recortado, fragmentado, o tempo paralisado; uma fatia de vida (re)tirada de seu constante fluir e cristalizada em forma de imagem. Uma única fotografia e dois tempos: o tempo da criação, o da primeira realidade, instante único de tomada do registro no passado, num determinado lugar $e$ época, quando ocorre a gênese da fotografia; e o gênese da representação, o da segunda realidade, onde o elo imagético, codificado formal e culturalmente, persiste em uma trajetória na longa duração. $O$ efêmero e o perpétuo, portanto. Perpétuo, porém em termos. ... destruídas ou desaparecidas... trata-se, pois, de uma memória finita. (KOSSOY, 2007, p.133)

É inegável a hegemonia e preponderância da fotografia como uma das principais fontes da preservação da atmosfera artística das obras teatrais. Quer seja para preservar a memória ou para divulgar e atrair o público para o espetáculo. Ao observar os materiais gráficos dos espetáculos teatrais, materiais de divulgação impressos e eletrônicos, publicações dos próprios grupos ou de terceiros, nota-se que a fotografia é bastante utilizada.

Por exemplo, na coleção Aplauso editada pela Imprensa Oficial, no livro dedicado ao ator Raul Cortez há cerca de duzentas imagens em uma obra de duzentas e quarenta e três páginas. Estas imagens mostram alguns momentos familiares, mas a grande maioria são registros de espetáculos teatrais em que Cortez atuou e algumas cenas de cinema e televisão. Estas imagens permitem um passeio pela carreira do ator em diversos momentos.

As formas de captação das fotografias de teatro podem ser feitas de modos distintos. O registro pode ser efetuado durante uma apresentação do espetáculo exclusiva para o fotógrafo. Desta forma, a mobilidade do fotógrafo na cena, próximo aos atores é maior, sendo permitido ao fotógrafo até interferir na composição da cena a ser fotografada, pois é possível que ele pare algumas cenas e peça aos atores poses específicas e diferentes dos movimentos naturais da cena. Este tipo de recurso é vantajoso quando a finalidade das fotografias é ilustrar o material promocional ou de divulgação do espetáculo. 
Outra possibilidade é fazer o registro durante uma apresentação com a presença do público. Desta forma o deslocamento do fotógrafo é mais limitado uma vez que ele não poderá estar em cena com os atores. O posicionamento dele será mais próximo ao ângulo de visão da platéia e não será possível interferir no ritmo da cena e nas poses dos atores. Porém, com os recursos das objetivas que aproximam as imagens, mesmo estando no mesmo lugar do espectador, o fotógrafo consegue resultados bastante distintos.

Pelo fato de não ser sempre possível afirmar com segurança as condições como as imagens foram obtidas, em alguns casos a imagem poderá deixar algumas dúvidas e causar sensações distintas aos observadores que as contemplarem.

Entre os artistas que trabalham com o teatro ou performance há algumas restrições sobre os usos feitos dos registros dos espetáculos. Laurie Anderson, performer norte-americana, no início de sua carreira era absolutamente contra qualquer tipo de registro de suas performances uma vez que o tema de seus trabalhos tratava justamente sobre tempo e memória. Ela achava que a melhor forma de gravação de suas performances seria a memória daqueles que presenciaram a sua execução. No entanto, algumas pessoas que assistiram às performances comentavam com ela alguns detalhes que não ocorreram. Por exemplo, algumas pessoas chegaram até ela disseram que adoraram o cachorro laranja que ela utilizou em uma apresentação. Ainda que ela nunca tivesse utilizado um cachorro laranja. Como as performances não foram documentadas ela não tinha como provar que não havia utilizado um cachorro laranja em sua performance. A partir deste fato, ela passou a documentar as suas performances para que o registro histórico dessas atividades fosse mais preciso ao que realmente ocorreu. Entretanto, quando uma arte feita para ser presenciada ao vivo é documentada em algum formato, este registro se torna uma outra forma de arte. Porém, este registro é fundamental para a perpetuação da memória da arte efêmera (ANDERSON, 2004. p. 6-7).

Ao analisar as fotografias do teatro é preciso ter clareza de que a

fotografia é memória enquanto registro da aparência dos cenários, personagens, objetos, fatos; documentos vivos ou mortos, é sempre memória daquele preciso tema, num dado instante de sua 
existência/ocorrência. É o assunto ilusoriamente re-tirado de seu contexto espacial e temporal, codificado em forma de imagem. Vestígios de um passado, admiráveis realidades em suspensão, caracterizadas por tempos muito bem demarcados: o de sua gênese e o de sua duração. (KOSSOY, 2007, p. 132)

As camadas a serem desvendadas são muitas. A foto pode ser apreciada apenas pelo seu potencial estético e artístico, mas também oferece indícios e elementos para resgatar ou (re)construir no imaginário individual e coletivo a atmosfera artística do teatro, cujo produto final é efêmero, mas que se perpetua por meio das imagens e textos que são legados à posteridade.

Segundo Pavis,

o interesse das fotografias para a análise é evidente já que são o traço tangível do que foi, um traço, todavia, que não leva necessariamente a conhecer o objeto fotografado, mas que propõe uma visão sobre uma obra de arte. A documentação fotográfica alivia a memória do comentarista, fornece-lhe pontos de referência e de fixação para uma descrição verbal (2005, p. 37).

Essas fotos podem interferir e alterar, positiva ou negativamente, a percepção daqueles que as utilizam como fonte de referência.

As formas de percepção são distintas quando se observa apenas uma única fotografia de um espetáculo de quando se observa esta fotografia acompanhada de formas complementares de registros e documentações. "A fotografia por ela mesma, não diz nada. É preciso fazê-la significar e para isso deve-se colocá-la em uma espécie de relação de atualização com outros elementos relativos à representação (restos, traços, descrição, texto...)" (VILLENEUVE apud PAVIS, 2005, p. 37) ${ }^{7}$.

Além do registro fotográfico dos espetáculos, fazem parte da construção do imaginário do universo artístico os retratos dos atores e das atrizes. Estes registros contam com uma produção bastante refinada e esmerada cuja função é melhorar e valorizar a aparência do retratado, trazendo glamour para reforçar e firmar o seu papel de celebridade.

\footnotetext{
${ }^{7}$ VILLENEUVE, Rodrigue. Les îles incertaines. L'objet de la sémiotique théatrale, Proteé, vol. 17, n1, 1989, p.28.
} 


\subsection{A HISTÓRIA AO ALCANCE DAS MÃOS}

Os livros históricos que celebram o aniversário dos grupos de teatro têm dois objetivos principais: registro e celebração. Trazem uma série de informações sobre a formação do grupo, metodologias de trabalho, processos de ensaio, dados sobre a origem dos atores e diretores. Apresentam uma história que o público que assiste aos espetáculos, em geral, desconhece. O exercício de compilação dos dados, seleção das imagens, gravação de depoimentos, quando agrupados e editados no formato de livro, possibilita um momento de reflexão sobre a trajetória percorrida e de lembranças dos momentos mais significativos dos integrantes dos grupos.

O livro histórico é um instrumento poderoso de institucionalização dos grupos de teatro. Ainda são poucos os grupos que publicaram sua história. Normalmente, são publicações feitas por grupos tradicionais e estruturados. Quantos grupos foram criados e deixaram de existir e não há mais nenhum rastro, nenhum registro? Por outro lado, há outros que acabaram, mas sua história está registrada e com isso a nova geração tem acesso a eles, por exemplo, Asdrúbal Trouxe o Trombone, Pod Minoga e Ornitorrinco. As publicações têm potencial para auxiliar muito a perpetuação da memória dos grupos.

A importância que as fotografias ocupam nos livros de história dos grupos de teatro é indiscutível. Elas potencializam a narrativa construída e evidenciam o passar do tempo no rosto dos atores.

Pelo fato de ocasionalmente haver um breve histórico em inglês da história dos grupos, é bastante provável que os livros sirvam como material de divulgação e apresentação do grupo para enviar aos festivais de teatro no exterior.

$\mathrm{Na}$ revista comemorativa dos dez anos da Sutil Companhia de Teatro, no texto de apresentação, Célia Arns de Miranda (2002, p. 2) comenta que "é imensurável a importância documental não apenas das entrevistas, como todo o material suplementar bastante adequado que são os textos e os vídeos de 
todos os espetáculos, a documentação crítica de caráter jornalístico, os programas das peças e o acesso aos ensaios"... "é o resgate de uma memória".

Já na apresentação do livro Palco lluminado, de Geraldo Peçanha de Almeida, Marta Morais da Costa afirma que

Tarefa árdua e penosa é trabalhar com a documentação de teatro. A arte volátil do palco contamina os documentos (fotos, programas, peças, figurinos, cenários). Passada a temporada, as mentes e mãos voltam-se para a próxima montagem, enterrando a recém-finda. [...]

Procede-se como se a memória dos artistas constituísse, por si só, um documento inalterável e fidedigno, capaz de ser sacada a qualquer momento e em qualquer circunstância com a devida nitidez e isenção.

A mudança de atitude é recente. A necessidade de manter atualizado e com a devida documentação o portfólio das realizações de grupos e companhias teatrais, devido à finalidade de obter subsídios e incentivos para novos empreendimentos, tem obrigado os elencos estáveis a registrar suas produções. Também o surgimento de bibliografia a respeito da história do teatro e de seus artistas, produzida principalmente em ambientes acadêmicos, originou maior atenção e cuidado na preservação de material de interesse de pesquisadores e estudiosos. $[\ldots]$

Cabe, pois, à escrita o registro em palavras - embora de maneira pálida e lacunar - e o dom de realizar a magia de representificar, de colocar de novo ante os olhos da memória ou da curiosidade, tudo o que de outro modo deslizaria para o abismo devorador do esquecimento. (COSTA, 2005, p. 15-16)

No mundo corporativo, quando uma empresa ou instituição comemora datas significativas, geralmente publica um livro sobre a sua história, contratando um escritor profissional para dar um tom a esta história. Com base em documentos e depoimentos oriundos de pesquisa e entrevistas será construída uma narrativa histórica da instituição e de seus fundadores. Normalmente, tratam-se de instituições com número expressivo de empregados, em que o foco da narrativa será os fundadores, os diretores, os acionistas, podendo também, em alguns casos, selecionar alguns empregados que representem os diversos níveis hierárquicos.

Em sua grande maioria, nos livros comemorativos dos grupos de teatro é comum que o escritor escolhido para narrar a história advenha de um ciclo do próprio grupo, por exemplo, um dramaturgo que trabalhe ou já tenha trabalhado com o grupo, permitindo ao autor (ou autores) da obra expressar as suas próprias lembranças, além dos materiais documentais textuais e iconográficos. 
Como os grupos de teatro são constituídos por pequenos grupos de artistas, técnicos e administradores, seus integrantes acabam aparecendo na obra. Quer seja por meio de fotos, de depoimentos, da sua história no grupo e, em alguns casos, por meio de textos de sua própria autoria.

Os aspectos principais desse tipo de narrativa são destacados por

Nassar

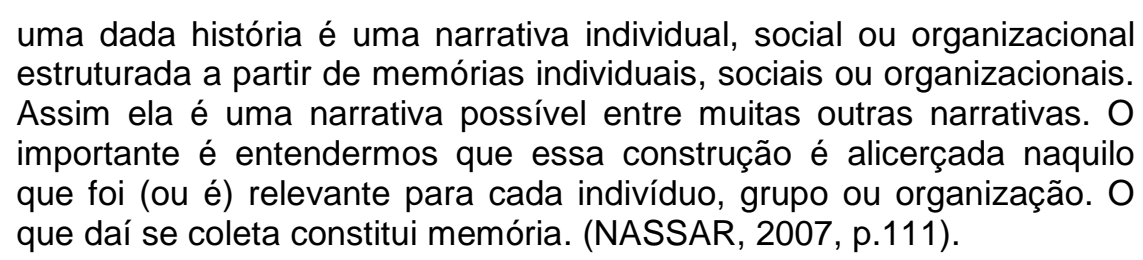

Desde o final dos anos noventa, nota-se uma produção constante de grupos de teatro que vêm trabalhando o registro de sua história em livros, DVDs, sites e mostra de repertório (apresentação de remontagens de peças encenadas em anos anteriores). Pretendem com isso projetar e (re) criar uma certa imagem a respeito de si próprios. Fazem parte da construção e ocupação do seu espaço simbólico, de uma auto atribuição de características e valores, realizada por meio de um recorte do "real".

Os livros e documentários tendem a contar a história dos grupos por meio de depoimentos e entrevistas de seus integrantes e geralmente possuem um rico material iconográfico. Nas publicações, a história tanto pode ser contada por meio de um texto narrativo escrito por autor convidado como pode conter ensaios escritos pelos diversos integrantes dos grupos de teatro, representando as diferentes áreas do fazer teatral.

Veremos a seguir uma descrição do livro comemorativo dos dezoito anos da Cia dos Atores, cuja finalidade é servir de guia e exemplo para a compreensão do contexto, finalidade e objetivos de publicação dessas obras.

Nos textos de apresentação do livro na Companhia dos Atores ensaios sobre os dezoito anos da Cia dos Atores, Enrique Diaz, diretor artístico da Cia dos Atores, expressa:

No momento dos 18 anos, em que, aos contínuos processos de criação e administração, somamos o trabalho de pensar a nossa trajetória, percebemos através da organização e catalogação de todo material fotográfico, viodeográfico, jornalístico e anotações de ensaio, a dinâmica 
de um corpo vivo. Um corpo coletivo arejado no tempo e no espaço, mas com uma leve e invisível membrana a lhe determinar o contorno.

(...) Não serve comemorar os 18 anos. Não serve ficar dizendo que nossa história é legal, é bacana. Serve dar o depoimento de que a arte é um ponto de vista, uma maneira de passar o tempo, é escolher a própria vida e seus contrastes e formas como alívio. Há sim, afinal, um modus operandi, há a fábula das relações, das soluções, das dores. Há o álbum de retratos, a prova de que não mentimos, de que estivemos lá, que não paramos, compulsivos que somos. (DIAZ et. al., 2006, p. 23-24)

O livro da Cia. dos Atores é composto por diversos artigos assinados por acadêmicos, pesquisadores de teatro e pelos próprios integrantes da companhia. Há trechos de entrevistas com todos os atores integrantes da companhia (a mesma pergunta feita a todos e suas respectivas respostas), linha do tempo, seleção de alguns textos de programas, seleção de algumas críticas de jornalistas, inclusive uma crítica que não elogia o espetáculo, ficha técnica de todos os espetáculos, relação dos prêmios recebidos, citação dos colaboradores que passaram pela companhia. É ilustrado com centenas de fotos, majoritariamente das encenações, porém há também fotos de processos de ensaio, bastidores, camarins. Exibe algumas reproduções de desenhos de figurinos e anotações de caderno de ensaios. Não segue uma linha cronológica rígida dos espetáculos e das imagens, tudo é mesclado.

O livro expande o seu caráter de história institucional, trazendo uma reflexão crítica e artística aprofundada, o que insere esta história na memória da comunidade. Cumprindo, portanto, uma função relevante para a institucionalização do grupo na memória teatral brasileira.

\subsection{LÍNGUAGENS HÍBRIDAS}

Com a simplificação e o barateamento dos equipamentos audiovisuais é cada vez mais comum o registro em vídeos dos espetáculos prontos e também dos processos de criação. Registros estes que podem ser feitos desde a forma mais simples e caseira até as "condições ideais" com múltiplas câmeras e técnicos oriundos do cinema. Os registros em vídeo tendem a ser dirigidos por profissionais da área do cinema ou documentário, oscilando entre o registro nu e cru do espetáculo a uma obra audiovisual autônoma. 
Os usos desses materiais também são distintos. Podem servir de videobook para enviar para festivais; servir de fonte de consulta e material de trabalho durante os processos de criação; ser utilizado como material de divulgação em sites, blogs ou Youtube e Vímeo, ser transformado em produto e comercializado ao público do teatro.

Uma das principais barreiras e tema controverso no meio teatral é assistir a um registro audiovisual de um espetáculo no cinema, na televisão ou na internet. Beth Néspoli, crítica de teatro do jornal O Estado de São Paulo durante quinze anos, em sua fala no II Congresso de Jornalismo Cultural realizado em maio de 2010 em São Paulo, comentou que o "teatro é a arte do estar com.(...) A única forma de se apreciar o espetáculo os sertões de José Celso Martinez Correa é assistindo às 18 horas de Os Sertões. Embora haja DVDs disponíveis da peça, não é a mesma coisa" (NÉSPOLI, 2010).

A pesquisadora francesa Beatrice Picon-Vallin nos apresenta um modo interessante de observar o fenômeno de transposição do teatro para o vídeo. Esta prática já é corrente e se acentua cada vez mais com as inovações tecnológicas disponíveis.

A passagem do espetáculo de teatro para a tela, direta ou derivada, total ou parcial, tem exatamente a mesma idade do cinema que, por sua vez, num segundo momento, se desligou dessa atividade para realizar obras originais a partir da adaptação de peças e textos teatrais. Portanto, os problemas advindos dessa passagem, sua frequência e suas modalidades, evoluíram em função da história das formas teatrais, das técnicas cinematográficas, das relações mantidas pelas duas artes, da intervenção da mídia televisiva e, atualmente, da incontornável ascensão das tecnologias da informação. (PICON-VALLIN, 2008, p. 151)

Por mais que o teatro seja uma arte milenar, a dinâmica social e cultural também exerce sobre ele pressões que promovem mudanças técnicas e estéticas.

Tal "querela", hoje em vias de apaziguamento, é a princípio, construída sobre um mal entendido: uma concepção de teatro imutável e imóvel, definido, antes de tudo, pela artificialidade. Se uma "ideia de teatro" lugar mítico, sagrado ou lugar poeirento, ou cristalizado nas dobras da cortina vermelha. (...) Devido à sua grande história, a noção de teatro parece não ter mudado. Entretanto, a teatralidade, está escrita em uma história e é preciso toda uma experiência da platéia e do palco para apreendê-la em uma globalidade não limitativa, e por meio de um efeito de profundidade, de volume e de densidade, ou de um jogo de contrastes. (PICON-VALLIN, 2008, p.153-154) 
Segundo Thom (1997), "a história das danças filmadas e posteriormente em vídeo e televisão nos últimos 70 anos tem sido uma fonte de promessas e desapontamentos assim como desafios e conquistas" (p. 90). Cita uma questão controversa que é normalmente um dos primeiros argumentos levantados para se desvalorizar os registros audiovisuais dos espetáculos,

Outros atribuem 0 valor dos filmes diferencialmente, como documentação. Para eles, o pavor era que a escolha do diretor da filmagem nos ângulos da filmagem poderiam infringir 0 olhar democrático do espectador. Closes faciais, que desfiguram a integridade da coreografia, a ênfase em solistas que excluem os grupos, a diminuição da força do movimento, e a ausência de profundidade são os problemas mais comuns gerados quando da transposição da dança do palco para a tela. (p. 90, tradução nossa)

A proximidade distante ou o distanciamento próximo que existe entre essas duas formas de expressão artísticas exercem uma tensão que provoca uma hibridização entre elas. "Teatro e cinema se interpelam, portanto, de maneira nova em uma cultura na qual as fronteiras entre as artes se confundem mais uma vez" (PICON-VALLIN, 2008, p. 160).

É preciso observar este fenômeno pelo seguinte aspecto,

O conceito de obra acabada corre o risco de se enfraquecer hoje nas passagens cada vez mais numerosas ligadas à mediatização, às reciclagens pelas telas, e às transformações incontroláveis da digitalização. Mas no teatro, onde ele nunca existiu, e no qual o inacabamento é de regra, a filmagem de um espetáculo pode se inscrever em um procedimento global. No mais das vezes work in progress, mesmo quando não é assim designada, uma encenação é uma das formas da vida de um texto na história, o espetáculo visto uma noite é uma de suas versões e o(s) filme(s), outra de suas manifestações possíveis. Assim, a obra cênica pode ser posta frente a frente com seu duplo - na língua "morta" das imagens traduzidas ou raptadas - suas sombras perenes capturadas pelo cinema e pelo vídeo. (...)

Nada substituirá a experiência única do palco e do público reunido, que o espetáculo transforma em comunidade, e a força das lembranças do teatro de Brook, de Mnouchkine ou de Kantor vem da força das emoções vividas em comum, a um só tempo fortalecidas e amenizadas em sua chama íntima pelo compartilhamento. Mas considerando a cena hoje, em suas manifestações concretas, o olhar do "estrangeiro próximo" pode também ser fonte de emoção. Se o filme de teatro toma emprestado do palco o princípio do encontro que lhe é próprio, transferindo o diálogo palco/platéia para o diálogo teatro/cinema, ele pode tornar-se objeto de um confronto dialético e fecundo entre dois autores, duas equipes, apesar das dificuldades para organizá-lo, geri-lo, realizá-lo. Perecível, o espetáculo é irreproduzível em sua imediatidade. Como todo objeto, ele é diferente de sua imagem...É preciso partir dessa evidência para tentar, ao filmar um espetáculo, apreendê-lo, ao menos em parte, destacando um fio condutor, imaginando um projeto de tradução por meio de um dispositivo específico. Procurar transmitir a emoção, a fragilidade do 
espetáculo ao retirar os riscos da atuação na gravação ao vivo._(PICONVALLIN, 2008, p. 160-1)

O aspecto presencial do teatro é a sua essência e nada poderá substituir essa experiência, porém, as novas tecnologias permitem atualmente novas formas e possibilidades de ter contato com os espetáculos e grupos de teatro. É claro que a forma de recepção será completamente diferente, porém, é uma forma de recepção, não pode ser ignorada e necessita de estudos específicos de recepção para se compreender melhor os efeitos causados no público.

É importante ressaltar que os filmes e vídeos de espetáculos não estão restritos a serem apenas documentação e registro do trabalho, podem também servir de material inspirador e criativo para uma nova obra artística. "Enquanto muitos artistas usaram o filme como uma forma de preservar e documentar o estágio de seus trabalhos, outros, particularmente Maya Deren, viu na dança filmada uma possibilidade criativa com a câmera atuando como um coreógrafo. (...)A captura dos artistas no ato de coreografia foi elevada a uma obra artística em si." (THOM ,1997, p. 91, tradução nossa).

A reprodução desse tipo de arte é uma outra forma de arte. Observa-se um movimento crescente de registros em mídias diversas, desde apenas um espetáculo até a história do grupo que são disponibilizados ao público. Os exemplos que conheceremos a seguir revelam a multiplicidade de ações, projetos e produtos que podem ser gerados a partir da memória de um grupo de teatro. 


\section{GRUPO GALPÃO: ONTEM, HOJE E SEMPRE}

Pelo fato deste estudo lançar um olhar sobre a memória de grupos de teatro, suas histórias, processos criativos e espetáculos, buscando demonstrar a relevância de se produzir e tornar públicos estes materiais para a construção da narrativa e institucionalização dos grupos de teatro, nos propusemos a fazer este estudo de caso, utilizando como fonte de dados os próprios materiais de comunicação e memória produzidos pelo Grupo Galpão e pelo Galpão Cine Horto, tais como livros, revistas, CDs e DVDs, programas dos espetáculos, o site do grupo na internet; além de publicações de pesquisadores focadas no Galpão, e sites de compartilhamento de vídeos online: Youtube e Vímeo.

Não é o escopo de nosso projeto relatar com minúcias de detalhes a história do Grupo Galpão ou o processo criativo de algum espetáculo específico, uma vez que estas informações estão disponíveis em uma série de publicações produzidas e editadas na maior parte das vezes pelo próprio grupo. Nosso interesse é na forma como o Grupo Galpão insere as informações relativas à sua história e memória nos materiais relacionados aos espetáculos ao longo dos anos e os produtos específicos gerados na comemoração dos aniversários do Grupo.

Este tipo de material pode ser classificado como uma forma expandida de comunicação e relacionamento entre o Grupo Galpão e seus públicos. Cada processo criativo, cada espetáculo gera inúmeros materiais e informações, cujos registros e documentações podem ser transformados em produtos (livros, CDs, DVDs) ou serem disponibilizados nas mídias online.

Com as possibilidades atuais de compartilhamento de informações de forma mais democrática e acessível e as transformações comportamentais trazidas pelas novas tecnologias, tais como fazer buscas na internet para acessar informações sobre grupos de teatro ou espetáculos teatrais, os conteúdos gerados a partir de fotos, textos e vídeos destes grupos ou espetáculos cumprem um papel de informação, divulgação e promoção do grupo e dos espetáculos fundamentais para o fortalecimento de sua imagem e 
reputação, tornando-os mais conhecidos e tendo o potencial de possibilitar o aumento do público para o espetáculo.

Este material pode despertar o interesse daqueles que ainda não tiveram nenhum contato com o Grupo ou com o espetáculo ao mesmo pode servir de gatilho para o público que já teve contato presencial com o conteúdo visualizado acessar em sua memória trechos do enredo, imagens de cenas, enfim, recuperar, resgatar, reviver sensações e pensamentos provocados pelo espetáculo.

O Grupo Galpão foi escolhido como objeto de nossa análise, pois constatamos que realiza um trabalho que vai além de ações pontuais de memória, tendo uma preocupação para com este tema desde a sua origem, e por estar desenvolvendo um projeto consistente há pelo menos quinze anos. Este projeto materializa-se por meio da edição de livros voltados à memória e história do Grupo, da publicação de textos do roteiro dos espetáculos e de diários de montagens, da gravação de CDs e DVDs, da manutenção de site e blog atualizados, e de um de seus maiores diferenciais que é fundação e manutenção do Centro de Pesquisa e Memória do Teatro, instalado no Galpão Cine Horto. Enfim, o projeto de memória do Grupo Galpão é um exemplo real que demonstra que os projetos de memória de grupos de teatro são possíveis, mas é necessário estar atento e identificar as oportunidades e formas de disponibilização deste material como elemento que agregue valor à construção e ao fortalecimento de imagem e reputação do grupo junto aos seus públicos. É seguramente um dos grupos que melhor trabalha seu projeto de memória, comunicação e relacionamento consistente e articulado com os espectadores.

\subsection{BREVE HISTÓRICO}

Remonta ao ano de 1982 o nascimento do Grupo Galpão, a partir de uma oficina com dois diretores do "Teatro Livre de Munique", da Alemanha, no Teatro Marília, em Belo Horizonte, MG. Dos participantes da oficina nove foram convidados para participar de um novo processo com os diretores alemães no Festival de Inverno da Universidade Federal de Minas Gerais - UFMG. Após o término deste processo, cinco dos atores e atrizes se reuniram e fundaram $o$ 
Grupo Galpão. Em novembro deste mesmo ano, estrearam no centro de Belo Horizonte o espetáculo de rua "E a Noiva Não Quer Casar..."

No ano seguinte, montaram o espetáculo infantil "De Olhos Fechados". O espetáculo "Ó prô cê vê na ponta do pé" foi apresentado na sequência. $O$ ano de 1985 foi marcado por um grande fracasso artístico e de público, o espetáculo "Arlequim Servidor de Tantos Amores", ocasionando assim uma grande crise no grupo.

Em 1986, o Galpão participou de uma oficina de criação teatral, novamente no Festival de Inverno da UFMG, desta vez na cidade de São João del Rey, e estabeleceu um importante contato com o diretor Ulisses Cruz, que resultou em um novo direcionamento à organização artística do grupo. Apresentou o espetáculo "A comédia da esposa muda" e participou como convidado do espetáculo "Triunfo, um Delírio Barroco".

A circulação do grupo em festivais internacionais no Brasil teve início 1987, ano em que o grupo teve contato com os grupos estrangeiros (Potlach e Tascabile, da Itália, Fará e Odin, da Dinamarca). No ano seguinte, montou o espetáculo "Corra enquanto é tempo". Os atores iniciaram e aprofundaram aulas e treinamentos vocais e com instrumentos musicais. Elementos marcantes até hoje no repertório de espetáculos do grupo. Participaram do Festival de Ayacucho, no Peru.

Em 1989, fizeram uma turnê de quase três meses pela França e Itália, passando pela cidade de Pontedera onde tiveram um encontro com o diretor polonês Jerzy Grotowski. Com o dinheiro da turnê e contraindo uma dívida de alguns mil dólares, o grupo adquiriu um imóvel que passou a ser sua sede na Rua Pitangui, 3.413, em Belo Horizonte.

Álbum de Família, de Nelson Rodrigues, foi a peça encenada em 1990. A convite do "Centro de Demolição e Construção do Espetáculo", em 1991, o Galpão apresentou, no Rio de Janeiro um repertório de peças.

Após um processo criativo com o diretor Gabriel Vilela, o grupo estreou o espetáculo "Romeu e Julieta", em 1992. Esta montagem original do Galpão alcançou muito sucesso e repercussão, fazendo com que o ano de 1993 
fosse marcado por temporadas em importantes parques e praças públicas do Rio de Janeiro, São Paulo e Belo Horizonte.

O ano de 1994 foi marcado por um acidente automobilístico que causou a morte de uma das atrizes fundadoras do Grupo, Wanda Fernandes. $O$ grupo estreou no Rio de Janeiro o espetáculo "A rua da Amargura".

Em 1995, o grupo remontou o espetáculo "Romeu e Julieta". Até este ano vários atores e atrizes entraram, saíram e retornaram ao grupo. Entretanto, os treze atores e atrizes que constituem o grupo atualmente se consolidou neste ano.

Participações em festivais internacionais na Inglaterra, Alemanha e Espanha marcaram o ano de 1996. O espetáculo "Um Molière Imaginário" estreou no ano seguinte. No ano de 1998, o grupo fez uma longa turnê internacional com os espetáculos "Romeu e Julieta" e "A Rua da Amargura" em festivais da Espanha, Holanda, Portugal, Costa Rica, Venezuela e Colômbia. Neste mesmo ano, foi criado o espaço cultural "Galpão Cine Horto". Em 1999, Partido foi o espetáculo criado pelo grupo.

A estreia do espetáculo "Um trem chamado desejo" e a temporada de "Romeu e Julieta" no Globe Theater, em Londres, foram os principais destaque no ano 2000.

Em 2001, o grupo circulou com vários de seus espetáculos para vários estados e regiões do país. E no ano de comemoração dos vinte anos do Galpão, 2002, foram realizadas mostras de repertório das últimas cinco montagens do grupo nas cidades de Belo Horizonte, São Paulo e Rio de Janeiro.

O espetáculo "O inspetor geral" foi montado e apresentado nos anos de 2003 e 2004. E no biênio seguinte - 2005 e 2006 - foi a vez do espetáculo "Um homem é um homem".

Em 2007 foi a estreia do espetáculo "Pequenos milagres", cujo processo criativo contou com a campanha "Conte sua história" que convidava o público do Galpão a enviar suas histórias por escrito para servir de base para a dramaturgia de um espetáculo do grupo. 
Em 2008, o grupo teve um contato maior com o cinema. Foi filmado o documentário "Moscou", de Eduardo Coutinho com direção teatral de Enrique Diaz, para a peça "As três irmãs", de Tchekov. Criou também quatro curtas metragens, a partir de uma oficina de cinema.

Em 2009, estreou o espetáculo "Till. A Saga de um Herói Torto", em 2011 estreou o espetáculo "Tio Vânia (aos que vierem depois de nós)". Até os primeiros quinze anos do grupo, houve a montagem de um espetáculo por ano, em média. Após este período, foi montado um espetáculo novo a cada dois anos.

\subsection{PRODUTOS E PROJETOS DE MEMÓRIA}

Em complemento à cronologia histórica do Grupo Galpão, nos interessa identificar os marcos principais relacionados aos lançamentos de produtos e projetos de memória do Grupo Galpão. Nosso estudo parte do lançamento, em 1999, do livro Grupo Galpão: 15 anos de risco e rito. Embora os quinze anos tenham se dado em 1997, o livro só foi publicado dois anos depois.

Em 2002, foram lançados os diários de montagens de quatro espetáculos do Grupo: Romeu e Julieta; A Rua da Amargura; Um Molière Imaginário; e Partido.

O Centro de Pesquisa e Memória do Teatro (CPMT) foi inaugurado nas instalações do Galpão Cine Horto em 2005.

O documentário em DVD intitulado Grupo Galpão: a história de um dos mais importantes grupos de teatro do Brasil, cujo conteúdo abrange vinte e três anos de história do Grupo foi lançado em 2006.

O ano seguinte, 2007, foi marcado pelo lançamento do livro comemorativo dos vinte e cinco anos do grupo galpão, O palco e a rua - a trajetória do teatro do Grupo Galpão. Esta publicação não pode ser caracterizada como um produto do grupo, mas sim um produto sobre o grupo. Trata-se de um olhar externo, pois o livro é fruto de uma pesquisa de nove anos, escrito a várias mãos por um grupo de pesquisadores acadêmicos. Portanto, um livro marcado muito mais pelo texto do que pelas imagens, uma obra de perfil mais acadêmico e menos literário. Além disso, foram lançados o DVD Romeu e Julieta no Globe 
Theatre e a coleção Espetáculos do Galpão com a publicação lançamento dos textos das principais peças do grupo: A comédia da esposa muda; Foi por amor; Corra enquanto é tempo; Romeu e Julieta; A rua da amargura; Um Molière Imaginário; Partido; Um trem chamado desejo; Pequenos Milagres e Um homem é um homem.

Há também um livro com as histórias enviadas para a peça Pequenos Milagres, cuja dramaturgia foi elaborada a partir do projeto "Conte sua história", na qual o Grupo convidava o público a lhe enviar uma história pessoal, e partir delas criar a dramaturgia do espetáculo. Foram recebidas quase 600 cartas e e-mails e, ao final, quatro delas serviram de base para o texto do espetáculo. Foi publicado um livro com algumas destas histórias.

Mais recentemente, foi publicado no ano de 2010 o livro: Grupo Galpão: uma história de encontros, de Eduardo Moreira, um dos fundadores do Grupo Galpão. A obra é co-editada pelo Selo Editorial criado em 2008 e intitulada Edições CPMT.

A seguir, detalharemos alguns destes produtos ou projetos realizados pelo Galpão.

Uma das obras de maior impacto visual que o Grupo já produziu é o livro comemorativo Grupo Galpão: 15 anos de risco e rito. De autoria de Carlos Antônio Leite Brandão, dramaturgo próximo ao Grupo uma vez que já havia trabalhado nas adaptações dos textos Romeu e Julieta e Um Molière Imaginário para o Grupo. Na introdução do livro, Brandão pontua que se trata de uma obra que supera o nível de mero registro documental, tendo uma característica que abarca o ensaio e a memória, o olhar crítico e o relato.

A ideia inicial era produzir uma publicação que registrasse os quinze anos do Grupo Galpão (...) e celebrar a história vivida pelo grupo (...) Mas se, além disso, tal história se erigisse como palco de uma reflexão do fazer teatral e se tornasse símbolo de uma trajetória de riscos e ritos, dramas e alegrias, próprias de sua benção dionisíaca, cumpria que o nível de registro fosse superado.

Ainda não sei bem definir o gênero em que este livro se enquadra: é algo que, além do caráter documental, desliza entre o ensaio e a memória, entre a consideração crítica e o relato, entre o acontecimento exibido na fotografia e o sentido que ele hoje toma para um olhar depurado pelo tempo e bem diverso daquele que o viu. Já dizia Heráclito ser impossível nos banharmos duas vezes nas águas do mesmo rio. Sendo rio, também o tempo me impede de recuperar a 
vivência original dos eventos aqui relatados. Nem as minhas lembranças são tão fixas: como nuvens elas adquirem sempre novas formas, conforme sopre o vento presente de nossas vidas, de nossos desejos e de nossas angústias. Ai reside um critério para selecionar o conteúdo dos textos e das fotos: figurações dos acontecimentos e momentos capazes de serem significativos para os leitores, aos quais cumpre enxergar novas formas nas nuvens da memória que aqui se apresenta. (BRANDÃO, 1999, p. 8-9)

O livro não deve ser visto apenas como um relato que descreve os acontecimentos passados da forma como ocorreram. A força do livro está na reflexão crítica que ele possibilita. Permite enxergar o passado com o olhar do presente, encontrando novos significados e interpretações.

A confecção de um texto totalmente novo, que deveria ir além do memorial e trazer uma reflexão mais crítica (...) a reflexão crítica está contaminada pelo fazer a que estamos continuamente afeitos. (...). Pois que seja esse o compromisso deste livro: fazer um acerto de contas com o passado e dar um balanço na história do grupo, ao qual pertenço de uma forma diferente, não para descrever os eventos tal como eles ocorreram, mas para desentranhar-lhes os sentidos ocultos e salvá-los para o presente. Aliás, não é outra a razão de ser do discurso do memorialista, do historiador, do crítico e mesmo do dramaturgo frente aos textos passados. Também aqui não é outra a pena que escrevo este livro: ele nada mais busca e expõe do que a dramaturgia de uma história e a maneira pela qual interpreto aquilo que foi vivido, até fazê-lo agente do que ainda está por viver." (BRANDÃO, 1999, p. 9-11)

O livro é uma edição com 178 páginas. Dividido em três capítulos, a história é contada de forma narrativa e cronológica. Repleto de imagens, cerca de 220 fotografias e alguns esboços de ensaios. Há um breve currículo e uma foto $3 \times 4$ de cada ator do grupo, que aparecem à medida que eles entram no grupo. Pequenos trechos de críticas jornalísticas surgem inseridos ao longo da narrativa. Ao final há fotos de todos os colaboradores e integrantes do Galpão, incluindo uma foto coletiva com todos os atores e seus filhos. Há uma área especial, uma página dupla com duas dobras adicionais formando um "folheto" com quatro páginas visíveis simultaneamente repletas de fotos com viagens do grupo pelo país e pelo mundo. A lista de todos os festivais que o grupo participou, a ficha técnica de cada espetáculo e um breve sumário em inglês.

Vale ressaltar que no livro não consta a marca de nenhum patrocinador. O que leva a crer que foi financiado integralmente com recursos do próprio grupo.

Em 2003, o grupo publicou os diários de montagem dos espetáculos Romeu e Julieta, A rua da amargura, Um Molière imaginário e 
Partido. Na apresentação dos livros lê-se: "esta publicação compõe-se de quatro livros nos quais são retomados os registros feitos diariamente durante os ensaios e processos de montagem de quatro peças do Grupo Galpão em Belo Horizonte". Esta publicação se aprofunda mais nas técnicas, nos métodos, nos desafios, e nas curiosidades que marcaram a montagem desde a ideia inicial até a estreia do espetáculo. No diário de montagem do Grupo Galpão - Livro 1: Romeu e Julieta, Brandão relata

O espetáculo aqui apresentado é outro e exibe as aventuras, os conflitos, os dramas e as alegrias próprias ao mundo teatral e aos que nele habitam diuturnamente. Sem dúvida, esse espetáculo é muito menos charmoso do que aquilo que os espectadores imaginam ao assistirem as peças. Mas é justamente nisso que reside o seu maior valor: aqui se conectam o mundo do teatro, o mundo da arte e o mundo da vida, com suas contingências, suas ansiedades e seus erros dentro dos quais construímos os caminhos de nossa liberdade e escrevemos a nossa história. [...]Nesse ponto, portanto, vai-se além do relato: temos uma história constituída pela linha que une os quatros livros e amarra as quatro peças a que nos dedicamos; temos uma memória, em que os acontecimentos e as ações são destilados da bruma do passado e das suas contingências para revelarem o seu sentido presente e sua fecundidade futura. (Brandão, 2003, p. 9 -10)

O grupo editou também uma coleção de textos de 10 montagens do Grupo Galpão. A coleção Espetáculos do Galpão é composta por oito volumes com o roteiro dos seguintes espetáculos: $A$ comédia da esposa muda; Foi por amor; Corra enquanto é tempo; Romeu e Julieta; A rua da amargura; Um Molière Imaginário; Partido; Um trem chamado desejo; Pequenos Milagres e Um homem é um homem. Ficaram de fora dois espetáculos do início do Grupo: $E$ a noiva não quer casar... e Ó pro cê vê na ponta do pé. Não são todas as peças do grupo que foram publicadas. As duas primeiras por serem marcadas por esquetes e números circenses não foram contempladas e também aquelas que são obras de autores consagrados do teatro que já possuem seus textos publicados em livros.

Os textos de teatro são elementos significativos para a preservação da memória do teatro. $\mathrm{Na}$ apresentação do patrocinador, Petrobras, presente em todos os volumes da coleção, reafirma esta questão, pois "o registro desses textos é o que constrói a memória do teatro. O Grupo Galpão, ao completar vinte e cinco anos de história, reuniu em livros os textos de suas mais significativas peças, que ajudam a contar a história e a evolução do grupo, que conquistou plateias no Brasil e no mundo". 
Os livros da coleção Espetáculos do Galpão trazem consigo, além do roteiro dos espetáculos, uma breve introdução que apresenta ao leitor o contexto no qual os textos foram criados, como estas obras chegaram ao grupo, peculiaridades e curiosidades dos processos de ensaio e da escrita da dramaturgia, assinados pelos dramaturgos e/ou diretores de cada um dos espetáculos encenados. O livro é bastante ilustrado com fotos de cenas das montagens.

Cacá Carvalho, diretor da montagem, toca em uma questão relevante sobre a finalidade destas obras, que é chegar e ampliar o contato com pessoas que não tiveram a oportunidade de assistir ao espetáculo presencialmente, mas que podem vir a ser tocadas por algum elemento dele. Em alguns espetáculos, "foram poucos os que viram, foram poucas as temporadas. Que pelo menos um pedaço dele fique. Escrito" (CARVALHO, 2007, p.11).

Das obras analisadas em nosso estudo a única que não se configura como produzida diretamente pelo Galpão é o livro $O$ palco e a rua - a trajetória do teatro do Grupo Galpão. Entretanto, por se tratar de uma pesquisa que se propõe a fazer uma análise crítica e conceitual de todos os espetáculos do grupo, esta obra exemplifica as possibilidades de se abrir a pesquisadores externos, disponibilizando informações, documentos e registros dos espetáculos e processos criativos, e com isso ter um público respeitado e formador de opinião, que endossa e institucionaliza o trabalho do grupo de teatro.

É o caso deste livro. Ele recupera a história dos textos criados e das encenações levadas ao palco pelo Grupo Galpão, em seu trabalho de renovação e divulgação, no Brasil e no mundo, do teatro mineiro e nacional. (...) reúnem aqui o conjunto abrangente de ensaios, que segue a trajetória do Grupo desde sua fundação até as criações mais recentes. Nesse percurso, os autores articulam informações preciosas sobre a inspiração, a construção e as interligações textuais da literatura dramática brasileira e internacional, bem como sobre a recepção e a crítica a cada peça. O leitor tem assim a capacidade de acompanhar todo o trajeto do Grupo em sua síntese, na melhor tradição antropofágica, da cultura brasileira e de clássicos ocidentais. (OLIVEIRA, 2006 p.14)

Há também um livro com as histórias enviadas para uma peça cuja dramaturgia foi elaborada a partir de um concurso de história que o grupo criou para receber histórias voluntárias do público nas quais quatro delas se 
tornaram o espetáculo Pequenos Milagres. Foi publicado um livro com algumas destas histórias.

A mais recente investida na área editorial foi a publicação do livro: Grupo Galpão: uma história de encontros, de Eduardo Moreira, um dos fundadores do Grupo Galpão, publicado no ano de 2010 pelo Selo Editorial criado em 2008 e intitulado Coleções CPMT.

Moreira expressa objetivamente $\mathrm{o}$ caráter memorialístico e pessoal sobre a história do grupo narrada no livro previamente citado, ao afirmar que

Mesmo deixando claro que essas narrativas estão mais próximas de uma visão pessoal que uma reconstituição histórica rigorosa, é preciso afirmar também que elas têm o mérito de ser um testemunho global, uma vez que eu fui a única pessoa que esteve presente integralmente durante do quase 30 anos de história do Galpão. (2010. p. 20)

O conteúdo do livro é fruto de postagens que o ator publicou no Blog do Elenco presente no site da companhia desde abril de 2007. Embora todo o elenco colabore para o blog, no livro, entraram apenas os post postados por Moreira.

Sendo as publicações impressas produzidas com tanto rigor e riqueza de informações e detalhes, dialogando sempre com a montagem criada, concordamos com Oliveira quando afirma "melhor que a leitura desta reconstituição analítica das criações do Grupo Galpão, só mesmo a presença em seus espetáculos, se eles pudessem todos ser reencenados em nossos dias" (OLIVEIRA, 2006, p.15). Como a probabilidade desses espetáculos serem reencenados é baixa, os livros, CDs e DVDs desempenham um papel de extensão e prolongamento das sensações geradas pelos espetáculos do grupo. 


\subsubsection{CDs com Trilha Sonora dos Espetáculos}

O primeiro produto gerado a partir de registros de espetáculos oferecidos para venda ao público do Galpão após os espetáculos foi o $\mathrm{CD}$ com a trilha sonora dos espetáculos Romeu \& Julieta e A Rua da Amargura, em 1995.

No livreto do primeiro CD produzido, Brandão afirma a intenção do CD em prolongar, no imaginário de seu público, o espetáculo visto, presenciado, experimentado, mas que não se repetirá mais.

Quando a cena final se desmancha e o Coro se vai, é através desses hinos que o teatro resiste no nosso imaginário, a invocar não só as cenas vistas como aquelas em que, num lampejo, prometemo-nos viver.

O Galpão não é um grupo musical. Faz teatro e é para prolongar esse teatro que ele produz este disco: nas suas músicas repercute o espetáculo visto e que não mais se repetirá. (...) Por ele, este disco, o teatro do Galpão resiste e se entrega a ti. Aproveita-o.

Na sequência foram lançadas as trilhas dos espetáculos: Um Molière Imaginário \& Um trem chamado desejo. E em 2007, na celebração dos 25 anos do grupo, foi lançado o CD das peças O Inspetor Geral \& Um homem é um homem.

\subsubsection{DVDs Documentário e de Espetáculos}

O DVD Grupo Galpão: A história de um dos mais importantes grupos de teatro do Brasil foi dirigido por Kika Lopes e André Amparo e teve a produção executiva de Paulo José. É um documentário permeado por gravações de depoimentos dos integrantes do Grupo Galpão, trechos e fotos de cenas de espetáculo e processos de ensaios. Como extra do DVD há o registro filmado da peça Corra enquanto é tempo, a ficha técnica de todas as peças do Grupo Galpão montadas até o momento, e um depoimento sobre a parceria do Grupo com o seu principal patrocinador, a Petrobras.

Os depoimentos individuais de cada integrante do grupo estão em preto e branco, e são intercalados com os trechos de cenas e ensaios. A história é contada de forma cronológica ao longo das duas horas e trinta e dois minutos do filme. 
Traz também um encarte com a síntese da história do grupo, a lista dos espetáculos montados, dos festivais nacionais e internacionais em que o grupo participou, de prêmios recebidos e a ficha técnica do Grupo Galpão, do Galpão Cine Horto e do próprio documentário.

Já o DVD Grupo Galpão em Londres - Romeu \& Julieta no Globe Theatre ou Shakespeare para inglês ver - o documentário, teve direção geral de Paulo José, trazendo um encarte impresso que contextualiza a forma de captação e registro das imagens, o processo de edição e como o grupo se relaciona com a obra. O DVD foi editado a partir de cinquenta horas de gravação efetuadas de forma fragmentada, durante a temporada do Grupo Galpão naquele teatro.

Os desafios para a estruturação do DVD do espetáculo eram enormes, pois as imagens haviam sido obtidas inicialmente para o DVD documentário do Grupo Galpão. Entretanto, ao avaliar o material, percebeu-se que havia registros suficientes para gerar um documentário sobre o espetáculo. Segundo José, diretor do documentário, "a melhor solução para estruturar este DVD: a inter-relação do palco com a plateia. Este DVD não é exatamente sobre a montagem do Romeu e Julieta do Galpão; é, isto sim, sobre os espetáculos memoráveis que o Galpão e os espectadores, juntos, fizeram no Globe Theatre de Londres de 11 a 23 de julho de 2000." 8

No mesmo encarte, o grupo afirma o desejo de perpetuar este espetáculo para as futuras gerações,

\begin{abstract}
A julgar pela emoção traduzida nas belas imagens desse DVD, acreditamos que a experiência foi única não só para nós, artistas envolvidos, mas para todos os que testemunharam aquelas apresentações.

Com o intuito de dividir esse momento com nosso público e de documentá-lo para as novas gerações é que preparamos esse registro de um espetáculo que se fez histórico, não só na trajetória do Grupo Galpão, como também no teatro brasileiro.
\end{abstract}

O DVD A Paixão Segundo Ouro Preto não é o registro filmado de espetáculo puro, mas uma versão adaptada para ser transmitida na TV Globo, a

\footnotetext{
${ }^{8}$ Encarte do DVD Grupo Galpão em Londres - Romeu \& Julieta no Globe Theatre, 2007. Item de arquivo pessoal do autor.
} 
partir do espetáculo A Rua da Amargura. A marca desta gravação são os cortes, os ângulos, o ritmo, a multiplicidade de espaços exteriores e interiores na cidade, característicos da linguagem televisiva. Entretanto, o texto, os personagens, atores, figurino, as canções, com alguns ajustes mantém a integridade estética e artística do espetáculo.

\subsubsection{Programas dos Espetáculos}

O documento físico mais antigo do Grupo Galpão que tivemos acesso é o programa do espetáculo Romeu e Julieta, distribuído ao público presente na apresentação deste espetáculo na esplanada do Teatro Pedro II, em Ribeirão Preto no dia 23 de agosto de 1993. No verso do programa, há o endereço físico do grupo, incluindo um número de telefone para contato, a lista dos dez espetáculos montados pelo grupo ao longo de seus dez anos e um parágrafo, registrando a trajetória do grupo que está transcrito a seguir: "O Grupo Galpão nasceu há dez anos atrás em Belo Horizonte, Minas Gerais. Conquistou, no decorrer deste tempo, um estilo próprio e original, transformando o teatro de rua num signo permanente do seu trabalho".

Estas informações, que em um primeiro momento parecem desnecessárias, demonstram que o grupo está aberto ao diálogo, uma vez que abre um canal de contato, no caso via correio ou telefone, a quem tiver interesse entrar em contato direto com o grupo. Quer seja para transmitir uma manifestação pessoal sobre o Grupo ou o espetáculo, e também para produtores culturais comprarem apresentações do espetáculo. É preciso ressaltar que, naquela época, não havia canais de comunicação na plataforma da online acessíveis em larga escala como atualmente. E raramente eram veiculados os endereços e telefones de contato de grupos de teatro em programas de espetáculos.

A listagem dos espetáculos demonstra um grupo bastante ativo com praticamente a montagem de um espetáculo por ano, e o parágrafo textual reafirma a importância histórica deste grupo no cenário teatral brasileiro. A insistência e permanência da lista do histórico de espetáculos montados é uma forma de dar uma perpetuidade a eles, ainda que seja apenas por meio de seu nome. 
Após este espetáculo, verificamos que a lista de todo o repertório de espetáculos do Grupo e o ano de sua montagem está registrada em todos os programas dos espetáculos a que tivemos acesso. Só não tivemos acesso aos programas dos espetáculos $A$ rua da amargura e do espetáculo atual do grupo, Tio Vânia (aos que vierem depois de nós).

A história do grupo se constrói a cada dia. Nota-se que o Grupo Galpão reafirma por meio dos programas impressos de seus espetáculos que valoriza e reconhece cada etapa desta trajetória. No texto de apresentação do programa do espetáculo Partido, referências aos marcos históricos de atuação do grupo estão explícitos na forma de texto.

Nosso trabalho com o diretor Cacá Carvalho marca o décimo sétimo ano de existência do Grupo Galpão. (...) No momento em que o Grupo Galpão alcança uma quase maioridade, esta montagem confirma os marcos que sempre caracterizaram o seu caminho desde os primeiros tempos - o espírito camaleônico e a capacidade de se adaptar a diferentes processos e linguagens, a jogar com as novas regras propostas ${ }^{9}$.

No ano de 2002, ao completar vinte anos, o Grupo apresentou uma mostra de repertório com cinco espetáculos criados nos dez anos anteriores: Romeu e Julieta; A Rua da Amargura; Um Molière Imaginário; Partido e Um Trem Chamado Desejo. Essa mostra circulou por três capitais brasileiras: Belo Horizonte, Rio de Janeiro e São Paulo. Esta ação permitiu que o público que já havia assistido aos espetáculos pudesse revê-los e o público que não havia assistido aos espetáculos anteriormente poderia fazê-lo neste momento.

Um folheto frente e verso com a ficha técnica do espetáculo reforça o compromisso do Grupo com a preservação, divulgação e compartilhamento de sua memória.

Chegar à marca dos vinte anos já nos dá razão suficiente para copiosas comemorações. Acrescente-se que chegamos a ela revestidos da mesma integridade e do mesmo vigor dos primeiros tempos. Envelhecemos, mudamos, crescemos. Trabalhamos com perseverança e alegria. Acumulamos reconhecimento, corremos mundo, fizemos muitos amigos. Sobretudo vivemos.

É dessa vida que queremos falar. E ela se expressa, com nitidez, através da diversidade do repertório montado nos últimos dez anos e

\footnotetext{
${ }^{9}$ Programa do espetáculo Partido distribuído durante sua temporada em São Paulo em 1999. Item de arquivo pessoal do autor
} 
que agora reunimos no evento "Galpão - 20 anos", nossa festa de aniversário. $^{10}$

O programa do espetáculo Um Molière Imaginário destaca, no texto de apresentação, a celebração dos vinte anos do Grupo. O título é: Grupo Galpão: 20 anos de estrada, tenacidade e poesia.

A partir de uma oficina realizada com membros do "Teatro Livre de Munique", seis atores reúnem-se em 1982 e fundam o Grupo Galpão. Não se tratava apenas de um nome para um grupo de teatro, mas, sobretudo, do comprometimento da vida de cada ator com um ideal comum, ao qual propunham consagrar a própria vida. Esse ideal assumiu três objetivos: ampliar a linguagem teatral, resgatar a cultura popular e atingir um público menos restrito do que aquele que freqüentava as tradicionais casas de espetáculo. (...) Esse compromisso, o mesmo assumido originalmente por aqueles seis atores, estende-se agora aos demais integrantes do grupo. É ele que os capacita a continuar celebrando o teatro. Por isso, ao comemorar vinte anos de estrada, nada melhor para o Galpão do que reafirmar esse compromisso, mantendo-o como um vetor que orienta o seu trabalho e renova o espírito de todos nós. (BRANDÂO, 2002) ${ }^{11}$

No programa do espetáculo Um homem é um homem, o texto assinado pelo patrocinador, Petrobras, reforça novamente o aspecto de tradição, longevidade e alta produtividade artística do grupo. "Ao longo de seus 23 anos de vida, o Galpão montou 16 espetáculos que foram vistos por cerca de $900 \mathrm{mil}$ pessoas em 380 cidades do Brasil e mais de 16 países. Com uma linguagem ousada e inovadora, resgatou vários elementos da mais profunda tradição do teatro".

O programa do espetáculo Till, a saga de um herói torto, também referencia o espetáculo dentro da trajetória do Grupo.

Este trabalho refaz e repensa toda a trajetória do grupo que, ao longo de seus vinte e sete anos de atividade, esteve sempre ligado aos cânones do teatro popular. (...) Completando vinte e sete anos de trabalho de grupo, acreditamos que esta nossa décima oitava montagem coroa o esforço que sempre norteou o Galpão, de realizar um teatro que concilie qualidade, pesquisa e encontro com o público. ${ }^{12}$

\footnotetext{
${ }^{10}$ Trecho de texto dos folhetos dos espetáculos Romeu e Julieta, Partido, Um Molière Imaginário, A Rua da Amargura e Um trem Chamado Desejo distribuídos na mostra comemorativa do Grupo Galpão por ocasião da comemoração de seus 20 anos, durante temporada em São Paulo, em 2002. Item de arquivo pessoal do autor.

${ }^{11}$ Trecho de texto do programa do espetáculo Um Molière Imaginário distribuído durante temporada do espetáculo em São Paulo, em 2002. Item de arquivo pessoal do autor.

${ }^{12}$ Trecho de texto do programa do espetáculo Till, a saga de um herói torto distribuído durante temporada do espetáculo em São Paulo, em 2010. Item de arquivo pessoal do autor.
} 
A repetição permanente e sucessiva de informações da história e memória do Galpão em seus programas indica uma intenção e um posicionamento claro que este Grupo quer ser percebido e associado à sua trajetória. E o Grupo aproveita múltiplas plataformas e suportes para transmitir esta mensagem.

Este nível de preocupação chega até a sofisticação de criar um conceito, um slogan, um mote para as suas celebrações. Tais como: Grupo Galpão - 15 anos de risco e rito, Grupo Galpão - 20 anos para o teatro e Grupo Galpão - 25 anos de encontros.

\subsubsection{Website do Grupo Galpão}

Um importante canal de comunicação que o Grupo Galpão mantém é o site na internet ${ }^{13}$. Descreveremos em seguida o tipo de informação disponível no site e percebemos que informações de caráter histórico e de memória ocupam um espaço relevante nesta mídia.

Na seção O grupo na página inicial do site da internet, a primeira linha já registra a idade do grupo: vinte e sete anos. Esta informação encontra-se desatualizada, pois o grupo já está com vinte e nove anos. Nesta mesma área, há a possibilidade de acessar a biografia resumida de cada um dos integrantes do grupo na seção Conheça a história de cada um. Os currículos são acompanhados de três fotos dos atores e atrizes caracterizados como personagens.

Os espetáculos são divididos em dois grupos na seção Espetáculos: aqueles que estão em repertório e aqueles que não são mais encenados. Estes estão apenas listados por escrito com um link para a sinopse, aqueles vêm acompanhados por fotos.

Uma linha do tempo contando a trajetória de vinte e cinco anos do Grupo Galpão pode ser acessada na seção História. Separados por décadas em três blocos: de 1982 a 1989, de 1990 a 1999 e de 2000 a 2007. Fotos, breve texto, foco nos espetáculos e destaque para encontros com encenadores

\footnotetext{
${ }^{13}$ Para conhecer mais sobre a proposta do grupo acesse http://www.grupogalpao.com.br.
} 
internacionais renomados e a criação do Galpão Cine Horto, da Campanha Conte sua História e do lançamento de publicações e DVDs.

O Galpão Cine Horto possui um site específico, que pode ser acessado pela seção Galpão Cine Horto ${ }^{14}$. Há, contudo um pequeno texto explicativo sobre o Galpão Cine Horto.

Na seção Galpão Free é possível que o público faça download gratuito de papel de parede para o computador, e de músicas no formato mp3 de dez canções de vários espetáculos do Galpão.

Em abril de 2007, foi criado o Blog do Elenco, acessado pelo link de mesmo nome, com postagens do elenco de textos e fotos de processos de criação, viagens, e impressões sobre questões relacionadas ao teatro. Este canal permite que o público acompanhe as atividades e os processos de criação e encenações dos espetáculos de forma permanente, constante e atualizada.

Na seção Notícias, são postados textos informativos do próprio Grupo. Já o calendário de apresentações dos espetáculos com informações básicas sobre o local da encenação e como adquirir ingressos, está na seção Agenda.

Há ainda dois espaços de acesso limitado a profissionais previamente cadastrados pelo grupo. Em Sala de imprensa, que se configura como um espaço de relacionamento com a imprensa onde são disponibilizados releases e fotos dos espetáculos em alta definição para download. O outro espaço é a seção Sala de produção que contém informações técnicas sobre a montagem dos espetáculos.

Para finalizar o grupo disponibiliza a ferramenta Fale Conosco, onde qualquer pessoa pode enviar um e-mail para o grupo.

\footnotetext{
${ }^{14}$ O Galpão Cine Horto é o centro cultural criado pelo Grupo Galpão. Para conhecer mais sobre o projeto acesse http://www.galpaocinehorto.com.br/
} 


\subsubsection{Centro de Pesquisa e Memória do Teatro}

O Centro de Pesquisa e Memória do Teatro (CPTM) foi criado para instituir o lugar da memória e da informação no cotidiano do centro cultural Galpão Cine Horto. O lugar guarda, armazena, gerencia e disponibiliza o acesso a informações, materiais, produtos da memória e da história do Grupo Galpão, do Galpão Cine Horto e o teatro de forma mais ampla.

É a concretização de uma prática que existia de maneira informal e não institucionalizada desde a fundação do Grupo.

Porque a memória era uma preocupação do Grupo Galpão e do Galpão Cine Horto desde o início, o que ficava evidente pelo volume do acervo de memória institucional acumulado até aquele momento, formado por fitas de vídeo, fotos e documentos bibliográficos que relatam a trajetória do grupo e que documentam as atividades do Galpão Cine Horto (RAMOS, 2008, p. 143)

O Grupo tem a consciência de que esta memória não pode ficar fechada e distante de seu público e dos interessados em teatro. "Em 25 anos de atividades como um grupo de teatro e em dez anos de centro cultural o Galpão acumulou uma memória que é não somente sua, mas de toda uma coletividade com a qual dialoga, da qual faz parte e para a qual direciona suas atividades" (RAMOS, 2008, p. 114).

Segundo Ramos, dentre os materiais do acervo do CPTM, aqueles diretamente relacionados ao Grupo Galpão e Galpão Cine Horto são constituídos por "livros, diários de montagem, fotos, cadernos, DVDs, vídeos e material gráfico das peças do Grupo Galpão. Textos, documentos de processo de pesquisa e criação; fotos e material gráfico; vídeo de DVDs de cada um dos projetos desenvolvidos no centro cultural Galpão Cine Horto" (RAMOS, 2008, p. 118).

O depoimento de Fernando Mencarelli a Ramos ressalta a importância do CPMT em disseminar a prática do registro e da documentação com qualidade, tendo em vista a possibilidade deste material estar disponível futuramente para um público mais amplo e por meio de suportes variados.

Essa disponibilização da informação, do acesso à informação, [...] tanto aquela que foi gerada ao longo desses anos e que está aí sendo registrada e agora sendo tratada para ser disponibilizada e a preocupação com o registro de tudo que se faz aqui, que também ele agora se torna um projeto, é preciso registrar, registrar com qualidade, ter o material para aquilo que foi eventual se perpetue como 
possibilidade de informação que seja mais acessível a um número maior de pessoas através de outros suportes, através do vídeo, através dos textos publicados. (RAMOS, 2008, p. 149)

Os espaços voltados à memória de grupos de teatro têm uma característica híbrida. Ramos classifica como "um espaço para a discussão da memória institucional e das especificidades dos centros de memória, que se caracterizam como modelo diferenciado de espaço, que não é um museu, não é um arquivo, tampouco uma biblioteca, mas um misto de todas as instituições, em escala menor" (RAMOS, 2008, p. 176).

Este olhar panorâmico sobre os diversos tipos documentais, suportes e projetos que o Grupo Galpão utiliza para perpetuar a história e a memória do Grupo e de seus espetáculos comprova que há múltiplas possibilidades de reverberação da produção artística do Grupo. Estes materiais, ao contrário do caráter efêmero dos espetáculos, trazem em si uma materialidade e uma força que apesar de não se aproximarem e muito menos substituírem a experiência presencial, ao trazerem vestígios da obra original, são fundamentais para perpetuá-las no tempo e fortalecer a imagem e a reputação do Grupo junto a seus públicos. 


\section{CONCLUSÃO}

O cenário atual relacionado aos pontos de contato, relacionamento e divulgação de um grupo de teatro com seus públicos, principalmente, com os seus espectadores, passa por transformações rápidas e profundas que requerem uma especial atenção por todos aqueles de vivem deste ofício.

Há uma série de recursos, canais, estratégias e atividades de comunicação e relacionamento à disposição das companhias de teatro e das peças que entram em cartaz que são pouco explorados ou utilizados de modo tímido, superficial e inadequado.

Embora o uso adequado das novas mídias seja o grande desafio colocado, é importante não se esquecer das mídias tradicionais. Não é porque um grupo tenha um site, um blog ou um perfil no Facebook que ele deixará de produzir um programa impresso do espetáculo, enviar releases para a imprensa, gravar um DVD, fazer um livro comemorativo ou publicar o roteiro de um espetáculo.

Obter reconhecimento é o que almeja qualquer indivíduo ou grupo que se expõe por meio de uma obra de arte. Quer seja uma pintura, uma escultura, um filme, uma música ou um espetáculo de teatro.

Normalmente, reconhecimento não é conquistado de forma fácil e simples. Demanda tempo, esforço e qualidade resultantes do trabalho do próprio grupo e a validação e legitimidade que são concedidos por terceiros, tais como, jornalistas, acadêmicos e espectadores.

Os grupos de teatro podem, contudo, exercer um papel pró-ativo em relação à sua legitimação e validação perante a sociedade por meio da execução de projetos e produtos de memória que contribuem de forma significativa no processo de sua institucionalização.

Observávamos o crescimento de produtos e projetos de memória de alguns grupos teatrais e nos propusemos a identificar as possibilidades de trabalho neste campo, uma vez que os resultados dessa atividade pode contribuir 
positivamente na imagem e reputação dos grupos de teatro, além de perpetuar suas histórias e espetáculos.

Uma vez que a arte se concretiza somente após o encontro entre artistas e espectadores, é necessário fazer uma análise e identificar quem é este público, saber onde transitam estas pessoas e elaborar estratégias para chegar até elas. Para o público chegar até o teatro é preciso que o teatro chegue a este público antes.

Por isso, é fundamental que grupos trabalhem de modo estruturado e mantenham canais de comunicação e relacionamento com seus públicos. Nos últimos anos, a plataforma online permitiu que os grupos criassem canais de diálogo direto, compartilhando seu o processo criativo e divulgando seu espetáculo.

É preciso romper, por parte dos artistas, com os preconceitos em relação ao mercado. Isso não significa se render às suas "leis", mas entender a sua dinâmica e usá-la a favor das artes. Por outro lado, cabe aos profissionais de gestão e comunicação que atuam no campo artístico, conhecer os limites da integridade artística dos espetáculos, para não descaracterizar a essência estética e poética da obra de arte.

Por meio de um processo contínuo do resgate de suas memórias, grupos de teatro iniciam projetos de memória buscando se fortalecer institucionalmente e permanecer para a posteridade, tentando assim lutar contra a efemeridade dos espetáculos do grupo e o esquecimento no tempo.

A identificação e análise criteriosa desses registros e documentos, em grande parte composto por textos, fotografias e vídeos, elementos constitutivos da formação artística do grupo permite ao grupo construir de forma pró-ativa a sua própria narrativa. Documentos históricos já existentes normalmente guardados em caixas, gavetas e armários de modo improvisado e fragmentado são conteúdos únicos e preciosos de informação e interesse público que está sendo pouco ou mal aproveitado pela maioria dos grupos de teatro.

Para os que assistiram previamente ao espetáculo, terão uma relação específica com este material, de forma a utilizá-lo como um estímulo que 
fará emergir em sua memória sensações, sentimentos, imagens e sons, remetindo a uma experiência real vivenciada no passado. O que nos lembra a experiência proustiana descrita no livro No caminho de Swann, no episódio em que uma madeleine desperta lembranças e memórias no narrador.

Para aqueles que não tiveram a chance de assistir presencialmente à encenação, este material cumpre uma função de despertar interesse e curiosidade. Pois caso gostem da imagem vista, do texto lido, provavelmente buscarão este encontro com o grupo quando tiverem oportunidade de assistir a um espetáculo.

O diferencial dos produtos ou projetos de memória é que eles não são perecíveis. Nas artes cênicas, o comum é haver o encontro entre artistas e público apenas durante as temporadas de espetáculos. Ou seja, os encontros ocorrem separados por semanas, meses e até anos. Entretanto, quando o grupo gera materiais que este público pode levar para casa ou acessar na internet, este espectador continuará se relacionando com a história, estética e a poética do grupo, ressignificando a experiência efêmera da encenação e, residualmente, estabelecendo uma proximidade afetuosa com o grupo.

Quanto mais profundas forem as experiências do público em relação a um grupo de teatro, mais este público terá a pré-disposição de acompanhar o repertório das novas montagens do grupo, indicá-lo aos amigos, e, neste ambiente de mídias sociais, expressar-se publicamente por meio de textos, imagens, enfim, ser cada vez menos um público "apenas" receptor, assumindo um papel de multiplicador dessa experiência.

Ao analisar o Grupo Galpão, percebemos que este grupo se utiliza dos mais diversos recursos, formatos, produtos e projetos de memória no sentido de preservar, prolongar e perpetuar seus espetáculos, sua história e sua memória.

Livros, CDs, DVDs, Centro de Memória e Referência, Site e Blog, compõem um conjunto de materiais disponíveis aos públicos do Grupo Galpão. Produtos estes que contribuem efetivamente para o seu fortalecimento institucional, para a formação uma identidade marcante, imagem e reputação consistentes, possibilitando a criação e a produção de peças com apoios e 
patrocínios permanentes, ampla visibilidade na mídia e, principalmente, atraindo mais espectadores para seus espetáculos. Que não se extingue ao fechar das cortinas, mas se prolonga por muito mais tempo. 


\section{REFERÊNCIAS}

ADORNO, Teodore. The Cultural Industry. New York: Routledge Classics. 1991.

ALVAREZ, José Carlos . Apresentação. In: Roteiro: Museu Nacional do Teatro. Lisboa: Instituto Português de Museus, 2005, p. 5-8.

ALVES, Junia. NOE, Marcia. O palco e a rua: a trajetória do teatro do grupo galpão. Belo Horizonte. Editora PUC-Minas, 2006.

ANDERSON, Laurie. This is the time and this is the record of the time. In: GOLDBERG, RoseLee. Performance live art since the 60s. New York: Thames \& Hudson, 2004.

AUGUSTO, Eduardo; YANAZE, Mitsuru H. Gestão estratégica da cultura: a emergência da comunicação por ação cultural. In: Organicom: Revista Brasileira de Comunicação Organizacional e Relações Públicas, ano 7, n.13, p., 2ํㅗㄴ semestre de 2010. p. 65-79.

AVELAR, Romulo. $O$ avesso da cena: notas sobre produção e gestão cultural. Belo Horizonte: DUO Editorial, 2008.

BARROS, Antonio Teixeira. A relação entre o sistêmico e o vivido na comunicação institucional. In: KUNSCH, Margarida M. K.; KUNSCH, Waldemar (org.). Relações Públicas Comunitárias: a comunicação em uma perspectiva dialógica e transformadora. São Paulo: Summus, 2007. p. 124-136

BENJAMIN, Walter. Magia e t'wcnica, arte e política: ensaios sobre literatura e história da cultura. Tradução: Sérgio Paulo Rouanet. 7. ed. São Paulo:

Brasiliense, 1994. (Obras escolhidas; v.1).

BERNSTEIN, Joanne Scheff. Arts Marketing Insights: the dynamic of building and retaining performing arts audiences. San Francisco: Josie-Bass, 2007.

BERTOLD, Margot. História mundial do teatro. Tradução: Maria Paula Zurawski, J. Guinburg, Sérgio Coelho e Clóvis Garcia. 2. ed. São Paulo:Perspectiva, 2004.

BOURDIEU, Pierre; DARBEL, Alain. 0 amor pela arte: os museus de arte na europa e seu público. Tradução: Guilherme João de Freitas Teixeira. 2. ed. São Paulo: Editora da Universidade de São Paulo, Porto Alegre: Zouk, 2007.

BOURDIEU, Pierre. A distinção: crítica social do julgamento. tradução Daniela Kern; Guilherme J.F. Teixeira. 2. ed. Porto Alegre, Zouk, 2011.

BRANDÃO, Carlos Antônio Leite. Grupo Galpão: 15 anos de risco e rito. Belo Horizonte: O grupo, 1999. 
BRANDÃO, Carlos Antônio Leite. Grupo Galpão: Diário de Montagem. Romeu e Julieta. Belo Horizonte: Editora UFMG, 2003.v.1.

CARVALHO, Cacá. Como enxergar um pedaço. In: Partido/ Ítalo Calvino; adaptação e dramaturgia por Cacá Brandão. Belo Horizonte: Autêntica/ PUC Minas, 2007. (Espetáculo do Galpão, 5) p.11-12.

CESNIK, Fábio de Sá.; BELTRAME, Priscila Akemi. Globalização da Cultura. Barueri Manole, 2005.

COSTA, Marta Morais da. Apresentação. In: ALMEIDA, Geraldo Peçanha de. Palco lluminado: 10 anos de história do festival de teatro de Curitiba. Curitiba: Ed. UFPR, 2005.

DIAZ, Enrique; OLINTO, Marcelo; CORDEIRO, Fábio (orgs.). Na companhia dos atores. Rio de Janeiro: Aeroplano, 2006.

DUARTE, Jorge; BARROS, Antonio (org.).Métodos e técnicas de pesquisa em comunicação. 2. ed. São Paulo: Atlas, 2010.

FONSECA, André. A gestão Cultural no contexto da dança. In: Projeto Em busca de novos caminhos para a dança contemporânea. Programa Municipal de Fomento à dança. IX Edição. MADUREIRA, Ângelo.e VIEIRA, Ana Catarina. (org.) 11p. Disponível em <http://anaeangelo.com/wpcontent/uploads/2011/06/GESTAO-CULTURAL-BAIXAR.pdf> Acesso em 24 jul. 2011.

FRIAS FILHO, Octavio. Da sombra até a luz. PINHEIRO, Lenise. Fotografia de palco. São Paulo: Editora Senac São Paulo / Edições SESC SP, 2008.p. 14-15.

HAMILTON, James. Understanding plays In: David Krasner and David Z. Saltz, Editors. Staging philosophy: intersections of theater, performance, and philosophy. Ann Arbor: The University of Michigan Press. 2006. p.221-243.

IPEA - INSTITUTO DE PESQUISA ECONÔMICA APLICADA. Obstáculos para o Acesso à Cultura dos Brasileiros, 2010.. Disponível em:<hppt://www.ipea.gov.br/portal/images/stories/pdfs/sips/101117_sips_cultura.p df > Acesso em: 31 jul. 2011

KLEEMANN, Fredi; MARCONDES, Tânia; VARGAS, Maria Thereza (Org.). Foto em cena. São Paulo: Secretaria Municipal de Cultura, 1991.

KOPP, Leslie Hansen. Dance Archives: a practical manual for documenting and preserving the ephemeral art. Preserve, 1995.

KOSSOY, Boris. Os tempos da fotografia: o efêmero e o perpétuo. Cotia, SP: Ateliê Editorial, 2007. 
KOTLER, Philip; SCHEFF, Joanne. Standing Room Only: strategies for marketing the performing arts. Boston: Harvard Business School Press,1997.

KOTLER, Philip. Foreword. In: BERNSTEIN, Joanne Scheff. Arts Marketing Insights: the dynamic of building and retaining performing arts audiences. San Francisco: Josie-Bass, 2007. p. VII-VIII

KUNSCH, Margarida M. K. (org.).Obtendo resultados com Relações Públicas: como utilizar as Relações Públicas em benefício das organizações e da sociedade em geral. São Paulo: Pioneira, 1997.

KUNSCH, Margarida M. K.; KUNSCH, Waldemar (org.). Relações Públicas Comunitárias: a comunicação em uma perspectiva dialógica e transformadora. São Paulo: Summus, 2007.

LEHMANN, Hans-Thies. Teatro pós-dramático. São Paulo: Cosac Naify, 2007.

LICIA, Nydia. Raul Cortez sem medo de se expor. São Paulo: Imprensa Oficial, 2007.

MACHADO NETO, Manoel Marcondes. Relações Públicas na difusão da produção cultural. In: KUNSCH, Margarida M. K.; KUNSCH, Waldemar (org.). Relações Públicas Comunitárias: a comunicação em uma perspectiva dialógica e transformadora. São Paulo: Summus, 2007. p. 273-289.

MACHADO NETO, Manoel Marcondes. O marketing é a mensagem. In: Organicom: Revista Brasileira de Comunicação Organizacional e Relações Públicas, ano 7, n.13, p., 2ํㅗ semestre de 2010. p. 49-64.

MELO, Jorge Silveira. Gotas de Sangue. Ou foram de suor? In Roteiro: Museu Nacional do Teatro. Lisboa, Instituto Português de Museus, 2005. p.13-18.

MENDONÇA, Carlos Magno Camargos. Cenário Cultural de Belo Horizonte: a comunicação em cena nos palcos de teatro e dança. In: Organicom Revista Brasileira de Comunicação Organizacional e Relações Públicas, ano 7, n.13, p., $2^{\circ}$ semestre de 2010. p.104-115.

MIRANDA, Célia Arns de. Os resgates de uma memória. In: Revista Sutil 10 anos, Curitiba, p.2-, dez.2002.

MIRANDA, Danilo Santos de. Uma fotógrafa em cena. In: PINHEIRO, Lenise. Fotografia de Palco. São Paulo: Editora Senac São Paulo/ Edições SESC SP, 2008. p.13.

MOREIRA, Eduardo da Luz. Grupo Galpão: uma história de encontros. Belo Horizonte, DUO Editorial, 2010.

NASSAR, Paulo. História e comunicação empresarial. Revista Comunicação Empresarial, São Paulo,n.31, p. 34-36, abr.jul. 1999. 
NASSAR, Paulo.Tudo é Comunicação. $2^{\underline{a}}$ edição revista e ampliada. São Paulo: Lazuli Editora, 2006.

NASSAR, Paulo. Relações Públicas na construção da responsabilidade histórica e no resgate da memória institucional das organizações. São Caetano do Sul: Difusão Editora, 2007.

NASSAR, Paulo. Conceitos e Processos de Comunicação Organizacional. In: Gestão Estratégica da Comunicação Organizacional e Relações Públicas. KUNSCH, Margarida M. K. (org.). São Caetano do Sul: Difusão Editora, 2008a. p. 61-75.

NASSAR, Paulo. Reputação é memória. Terra Magazine, 12 nov.06b. Disponível em <http://terramagazine.terra.com.br/interna/0,,Ol243291-El6786,00.html> Acesso em 17 jan. 2008b.

NÉSPOLI, Beth. A crítica de teatro e a produção contemporânea. CONGRESSO DE JORNALISMO CULTURAL, n.2, 3-6 maio 2010, São Paulo. 2o Congresso de Jornalismo Cultural, São Paulo, 2010.

OLIVEIRA, Solange Ribeiro de. Apresentação. In: ALVES, Junia. NOE, Marcia. 0 palco e a rua: a trajetória do teatro do grupo galpão. Belo Horizonte. Editora PUC-Minas, 2006. p. 13-15.

PAVIS, Patrice. A análise dos espetáculos: teatro,mímica, dança, dança-teatro, cinema. tradução Sérgio Sálvia Coelho. São Paulo: Perspectiva: 2005.

PICON-VALLIN, Béatrice. A cena em ensaios. São Paulo. Perspectiva, 2008.

PINHEIRO, Lenise. Fotografia de palco. São Paulo: Editora Senac São Paulo / Edições SESC SP, 2008.

PRADO, Décio de Almeira. Fredi Kleeman: ator e fotógrafo. In: KLEEMANN, Fredi; MARCONDES, Tânia; VARGAS, Maria Thereza (Org.). Foto em cena. São Paulo: Secretaria Municipal de Cultura, 1991.

RAMOS, Luciene Borges. Centros de Cultura, Espaços de Informação: Um estudo sobre a ação do Galpão Cine Horto. Belo Horizonte: Argvmentvm, 2008.

REBELLO, Luiz Francisco. Sonhar (com) o teatro. In Roteiro: Museu Nacional do Teatro. Lisboa, Instituto Português de Museus, p. 9-12, 2005.

REIS, Ana Carla Fonseca. Economia da cultura da dança - do nascimento à meiaidade In: Projeto Em busca de novos caminhos para a dança contemporânea. Programa Municipal de Fomento à dança. IX Edição. MADUREIRA, Ângelo.e VIEIRA, Ana Catarina. (org.) Disponível em < http://anaeangelo.com/wpcontent/uploads/2011/06/ECONOMIA-BAIXAR-.pdf> Acesso em 24 jul. 2011. 
ROSENFELD, Anatol. A Arte do Teatro: aulas de Anatol Rosenfeld (1968) registradas por Neusa Martins. São Paulo: Publifolha, 2009.

SANTOS, Vítor Pavão dos. A Criação do Museu. In Roteiro: Museu Nacional do Teatro. Lisboa, Instituto Português de Museus, p. 31-36, 2005.

SOBRAL, Sonia. Os públicos no plural ou os públicos no singular. In: Projeto - Em busca de novos caminhos para a dança contemporânea. Programa Municipal de Fomento à dança - IX Edição. MADUREIRA, Ângelo.e VIEIRA, Ana Catarina. (org.) Disponível em <http://anaeangelo.com/wpcontent/uploads/2011/06/PUBLICOS-BAIXAR.pdf> Acesso em 24 jul. 2011.

STUMPF, Ida Regina. Pesquisa bibliográfica. In: DUARTE, Jorge; BARROS, Antonio. Métodos e técnicas de pesquisa em comunicação. São Paulo: Atlas, 2010, p. 51-61.

THOM, Rose Anne. Capturing the ephemeral art. In Dance Magazine. New York, v.71, n.11, p. , nov. 1997.

TOLILA, Paul. Cultura e Economia: problemas, hipóteses, pistas. Tradução Celso M. Pacionik. São Paulo: lluminuras / Itaú Cultural. 2007.

URBINE, Lia. Memória em processo. In: CARVALHO, Sérgio de. (org). Introdução ao teatro dialético: experimentos da Companhia do Latão. São Paulo: Expressão Papular; Companhia do Latão, 2009.

YIN, Robert. Estudo de Caso: planejamento e métodos. 2 ed. Porto Alegre: Bookman, 2001. 